
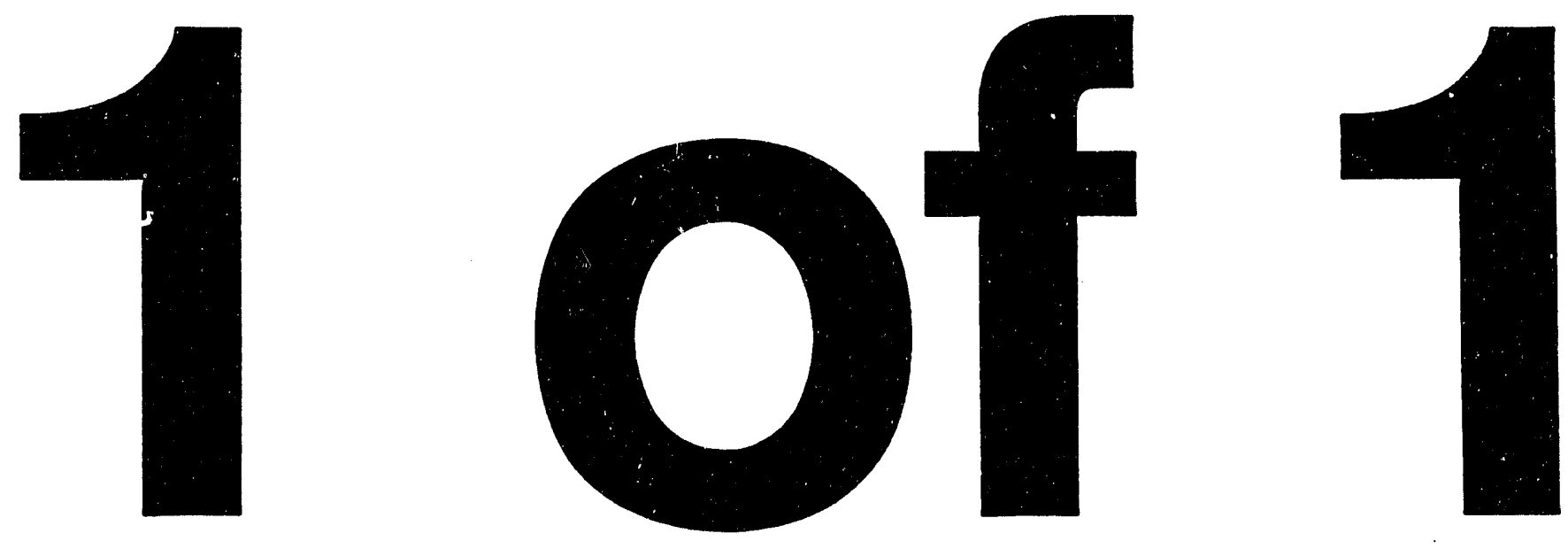
LBL-35919

UC-000

\section{TRANSPORTATION ENERGY USE IN MEXICO}

Claudia Sheinbaum, Stephen Meyers, and Jayant Sathaye

Energy Analysis Program

Energy and Environment Division

Lawrence Berkeley Laboratory

University of California

Berkeley, CA 94720

July 1994

This work was supported by the Office of Environmental Analysis, Office of Policy, Planning and Program Evaluation, U.S. Department of Energy through Contract No. DE-AC03-76F00098. 


\begin{abstract}
This report presents data on passenger travel and freight transport and analysis of the consequent energy use in Mexico during the 1970-91 period. We describe changes in modal shares for passenger travel and freight transport, and analyze trends in the energy intensity of different modes. We look in more detail at transportation patterns, energy use, and the related environmental problems in the Mexico City Metropolitan Area, and also discuss policies that have been implemented there to reduce emissions from vehicles.
\end{abstract}




\section{TABLE OF CONTENTS}

1. INTRODUCTION $\ldots \ldots \ldots \ldots \ldots \ldots \ldots \ldots \ldots \ldots \ldots \ldots \ldots \ldots \ldots \ldots \ldots \ldots$

2. TRANSPORTATION POLICIES AND INFRASTRUCTURE DEVELOPMENT $\ldots \ldots 1$

3. OVERVIEW OF TRANSPORT ENERGY USE $\ldots \ldots \ldots \ldots \ldots \ldots \ldots$

4. PASSENGER TRANSPORTATION

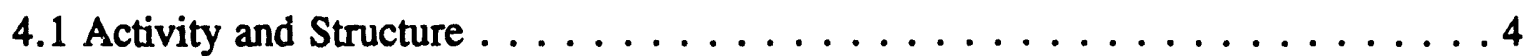

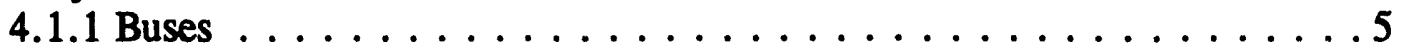

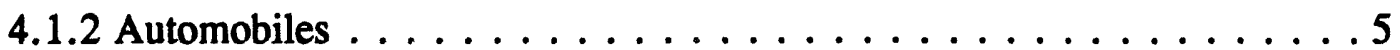

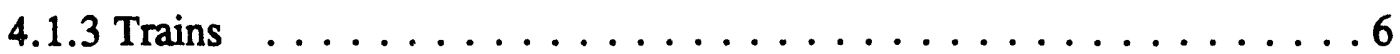

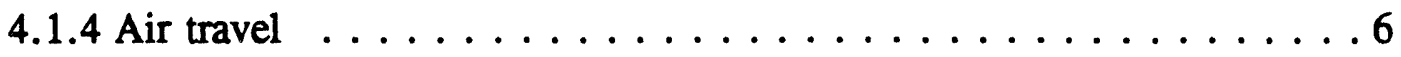

4.1.5 Urban and interurban passenger transportation in $1990 \ldots \ldots \ldots \ldots 7$

4.2 Energy Use and Intensities $\ldots \ldots \ldots \ldots \ldots \ldots \ldots \ldots$

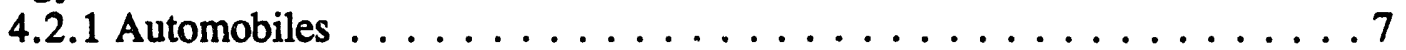

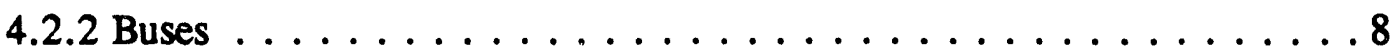

4.2.3 Other $\ldots \ldots \ldots \ldots \ldots \ldots \ldots \ldots \ldots \ldots \ldots \ldots \ldots \ldots \ldots \ldots \ldots$

\section{FREIGHT TRANSPORT}

5.1 Activity and Structure $\ldots \ldots \ldots \ldots \ldots \ldots \ldots$

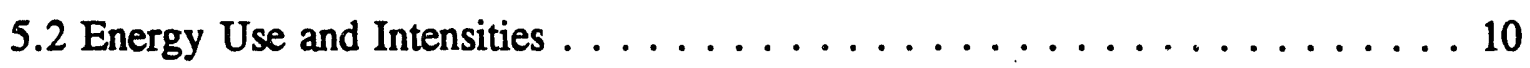

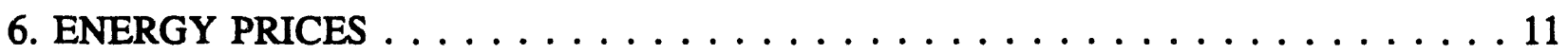

7. TRANSPORT IN MEXICO CITY METROPOLITAN AREA $\ldots \ldots \ldots \ldots$

7.1 Passenger Transportation . . . . . . . . . . . . . . 12

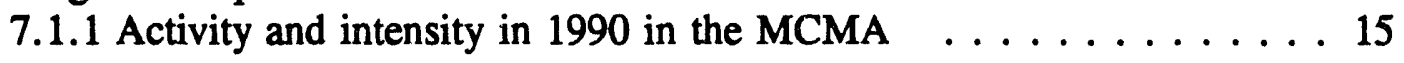

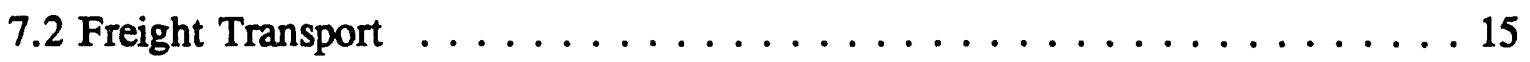

7.3 Environmental Problems in the MCMA $\ldots \ldots \ldots \ldots \ldots$

7.4 Transportation Policies in the MCMA $\ldots \ldots \ldots \ldots \ldots \ldots$

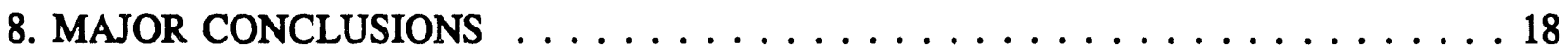

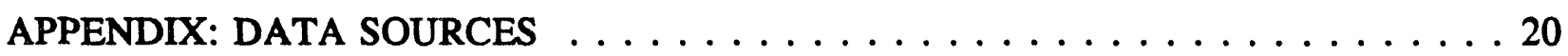

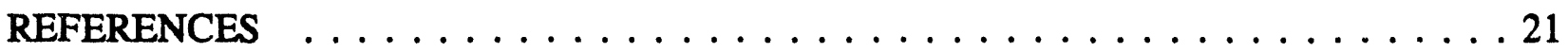




\section{INTRODUCTION}

Energy consumption in the transport sector in Mexico grew at a rapid rate in the 1970s. During the period of economic recession and stagnation in the 1980s, transport fuel demand was flat. As the Mexican economy began to grow in recent years, transport energy use has increased at a fast pace.

Transportation plays an important role in Mexico's energy economy. Its share of total final energy use, $33 \%$ in 1970 , has risen to $40 \%$ in 1991 , while its share of total oil consumption has increased from $59 \%$ to $65 \%$. The growth of oil use in transport means that more of Mexico's oil resources must be devoted to meet domestic demand, thus leaving less for export earnings in the long run.

The growth in transport energy demand has been associated with rising use of motor vehicles in urban areas, which has caused a large increase in congestion and air pollution. Air pollutant concentrations in Mexico City routinely exceed World Health Organization guidelines, and emissions from vehicles are the largest contributor to the pollution. Although increasing attention is being given to air pollution concerns by the Mexican government, economic growth will bring continued growth of the vehicle fleet, especially since adequate public transport is lacking.

An understanding of the factors shaping trends in energy use in the transport sector is important both for projecting what future oil demand might be and for designing effective policies for saving energy and reducing vehicle emissions. This report presents data and analysis of passenger travel and freight transport and the consequent energy use in Mexico during the 1970-91 period. The section following this introduction describes transportation policies and infrastructure development in Mexico since 1970. Section 3 is an overview of transport energy use. Section 4 analyzes passenger travel and its energy use, while freight transportation is addressed in the next section. Section 6 describes the changes in energy prices. Section 7 looks in more detail at transportation patterns, energy use, and the related environmental problems in the Mexico City Metropolitan Area.

\section{TRANSPORTATION POLICIES AND INFRASTRUCTURE DEVELOPMENT}

In order to understand the changes in the Mexican transportation sector, it is useful to give a brief overview of the transport infrastructure development and the transportation policies associated with it.

Between 1970 and 1980, considerable road infrastructure was developed in Mexico. The length of main roads in 1990 was twice that of 1970 , while secondary and 
local roads grew by a factor of seven (Informe de Gobierno 1992). After 1973, however, the total number of motor vehicles increased more rapidly than road length. This deterioration in the availability of roads per vehicle was caused by a reduction of the funds available for construction and maintenance of roads. Between 1970 and 1975 public investment for transportation represented near $1.3 \%$ of the GDP, while between 1976 and 1990 it represented an average of $0.8 \%$. In the early 1970 s the share of "roads and bridges" in the federal investment for infrastructure was near $65 \%$, while in the following years it never went over $55 \%$.

Interurban rail infrastructure was developed during the early part of this century, and few investments have been made toward improving and expanding the national rail system since 1970 . On 26,399 kilometers of principal track, $97 \%$ of the rail equipment is used for freight transport.

Transportation policies in Mexico, as well as other governmental plans, are redefined every six years, when a new administration assumes the federal government. Each new administration develops new transportation goals, which usually are different from those of the preceding administration.

Between 1970 and 1976, the Transportation National Plan set several major goals (Islas 1992): (a) Equal opportunity for private and public transportation, (b) Subsidization of transportation, especially freight transport, to promote economic development, (c) Priority to the development of road transportation, and (d) Encouragement of automobile production.

Between 1976 and 1982, key transportation policies included: (a) A large increase in public investment in transportation; (b) Extension of the road system, especially in some regional zones where economic growth was planned; (c) Increase of tariffs in order to finance the road investment; and (d) More investment in trains and air transportation.

Most of these goals were not satisfied for many reasons. Perhaps the most important one was the increased investment of the federal government in the oil sector (during the "oil boom" period) to the detriment of others. During the oil boom, the transport system received great pressure due to an increase in oil exports and agriculture imports. In 1980, the national freight transport system was unable to distribute either the increased agricultural imports or some manufacturing and oil products (Islas 1993).

For the 1982-88 period, the major transportation energy policies were: (a) Extension of the transport system to the whole territory, (b) Improving the linkage between the freight transport and agriculture storage systems, (c) Improving the transport links with the U.S., (d) Intensive use of labor to maintain the road infrastructure, and (e) Achieving greater economic self-sufficiency for the sector. Few of these goals were realized, however, as Mexico found itself in a severe economic crisis at the end of 1981 (provoked in part by the fall in oil prices and the large external debt). In addition, high 
rates of inflation and decreased purchasing power provoked a contraction in the internal demand, which was reflected in reduced demand for transportation services.

In 1988, the incoming Salinas administration greatly increased the process of economic liberalization. For the first time in many decades development of road infrastructure by private companies was allowed in some regions. State-owned airlines were sold and the train system was put up for sale. The 1989-94 "Plan Nacional de Desarrollo" targeted urban transportation as the main transport problem and described the main transportation objectives as follows: (a) Increase roads to the marginal urban zones and to suburban and rural zones near cities, (b) Restructure public transportation in the cities, (c) Allow operation of public transport (such as microbuses) by private companies, and (d) Increase transportation tariffs (removal of subsidies) in an equitable way.

The above review of Mexico's transport policies shows how both priorities and ideology regarding the role of the private sector have shifted over the past two decades. It also shows how the implementation of policies regarding public investment in the transport sector were severely hampered by the economic recession of the $1980 \mathrm{~s}$. This lack of investment helped to condition the trends in transportation described in the following sections.

\section{OVERVIEW OF TRANSPORT ENERGY USE}

The transport sector in Mexico is responsible for over $40 \%$ of total final energy use. In 1991, transport used around $1400 \mathrm{PJ}$ of energy (255 million barrels of oil). Oil products represent more than $99 \%$ of its energy use, and the share of transport in total oil consumption increased from 59\% in 1970 to $65 \%$ in 1991.

Mexico's transport energy demand has been sensitive to annual changes in GDP (Figure 3.1). From 1970 to 1978 transport energy use increased steadily at an average annual rate of growth of $7.9 \%$. Between 1978 and 1981, the oil boom years, transport energy use grew at $8.9 \%$ per year. Transport energy use decreased with the sharp drop in GDP between 1981 and 1983. Between 1983 and 1988 the economy grew somewhat, and transport energy demand rose at a modest $1.9 \%$ per year. Between 1988 and 1991 , the Mexican economy began to grow more rapidly, and transport energy use increased at an annual rate of $7.9 \%$.

The share of gasoline in total transport energy use decreased from $65 \%$ in 1970 to $60 \%$ in 1980 but increased again to $65 \%$ in 1991 (Figure 3.2). In contrast, the diesel share increased from $28 \%$ in 1970 to $32 \%$ in 1980 , but then decreased to $25 \%$ in 1991 . The faster increase in diesel demand during the 1970s was brought about by growth in the truck fleet as well as a switch from gasoline to diesel for heavy freight trucks and interurban passenger buses (CONAE 1992c). The fall in diesel and the increase in 
gasoline demand during the 1980 s was caused by two main factors. One was the economic recession, which brought reduction in freight movement. The second was the increase in the number of cars and gasoline-fueled light trucks.

Table 3.1 and Figure 3.3 show the changes in transport demand by fuel and by mode for 1975, 1983, 1988, and 1990 (with exception of buses and trucks for 1990). Road transport accounted for more than $90 \%$ of the energy use in the four years. Cars and taxis increased their share of energy use from $37 \%$ in 1975 to $45 \%$ in 1990 . Between 1975 and 1988 the bus share increased from $11 \%$ to $14 \%$, while trucks (including light trucks) decreased its share from $39 \%$ to $32 \%$. Water and air transport maintained their shares at about $2 \%$ and $5-6 \%$ respectively, while trains decreased its share from $5 \%$ to $2 \%$.

\section{PASSENGER TRANSPORTATION ${ }^{1}$}

Energy use for passenger transportation accounts for close to two-thirds of total Mexican transport energy use. Energy use for passenger transport is a function of the overall level of motorized travel, which we call "activity," the mode used, and the energy intensity of various modes.

\subsection{Activity and Structure}

Passenger travel activity is usually expressed as passenger-km, which is a measure of the number of passengers transported and the distance traveled. Structure refers to the shares of total activity accounted for by each mode of transportation. A time series of passenger-km is available only for interurban buses, interurban trains, and airplanes. However, occasional surveys make it possible to build a picture of Mexican travel for 1975, 1983, 1988 and 1990 for all modes with the exception of light trucks (Table 4.1) (CONAE 1992c, DDF 1992, Informe de Gobierno 1992).

Passenger travel grew at an average annual rate of 5.8\% between 1975 and 1990 , around three times the growth in GDP. Passenger-km per capita increased at an annual average rate of nearly 3.5\%, reaching the level of 8.2 passenger-km per capita in 1990 . This was $70 \%$ lower than in the U.S. but only $21 \%$ less than in the U.K. (Schipper et al. 1993).

Intensive use of public transportation has continued to dominate passenger travel in Mexico. As shown in Table 4.1, buses represent over $60 \%$ of passenger travel, while cars represent around 33\%. The share of cars actually declined from 1975 to 1983, but has risen since then.

\footnotetext{
1 Light trucks, motorcycles, bicycles and walking are excluded from this analysis due to lack of data.
} 


\subsubsection{Buses}

Between 1970 and 1990 the total number of buses, not including microbuses, increased at an average rate of $8 \%$ per year. The number of buses increased from 0.64 per 1000 inhabitants to 1.16 . In order to understand the changes in bus travel, it is important to look separately at urban and interurban buses.

Interurban buses are owned by about 25 private companies. They are the principal mode of transport between different states or cities. Reflecting the economic circumstances, interurban bus travel grew at an annual rate of $13.7 \%$ between 1975 and 1983, but at only 6\% between 1983 and 1990 .

The number of interurban buses grew considerably during the oil boom years (Figure 4.1). The average annual distance traveled by an interurban bus increased slightly from $110,000 \mathrm{~km}$ in 1975 to $120,000 \mathrm{~km}$ in 1990 . At the same time, bus load factor increased 15\% (CONAE 1992c).

Interurban bus travel recorded the highest increase of all modes. The significant migration from the country side to the urban areas probably was or: of the main causes. The new urban immigrants travel to their old homes to visit their families, and vice versa. Another possible reason for the increase of this mode is related to travel for seasonal employment, such as agriculture.

Urban buses are either private, municipal, or state-owned. In the Federal District, for instance, the bus fleet was private until 1980, when it was nationalized. From 1975 to 1983 urban bus travel grew at an annual rate of growth of $7.8 \%$, but it barely grew from 1983 to 1990 . The lack of growth was due to several factors. One was the lack of capital investment by the states and the municipalities to replace and buy new vehicles. Another was the fact that many small private owners of public buses went out of business during the recession.

In the late 1980s and early 1990s, two other transport modes emerged in the larger Mexican cities to compensate for the lack of standard buses. Privately owned vans and microbuses, with less than half the standard bus capacity, took an important share of the bus service. This phenomena occurred in many other Latin American cities as well (Darbera 1993).

\subsubsection{Automobiles}

Estimated automobile passenger travel increased at an annual rate of $6.6 \%$ between 1975 and 1983 and at $4.1 \%$ from 1983 to 1990 . The average annual distance driven per car decreased from $20,000 \mathrm{~km}$ in 1975 to $18,300 \mathrm{~km}$ in 1983 but increased to $20,200 \mathrm{~km}$ in 1990 . For the same period, the estimated automobile load factor decreased from 2 to 1.6 persons per vehicle. Since the annual distance traveled per car 
changed only marginally, and the load factor declined, the increased travel was due entirely to the large increase in car ownership.

The considerable development of urban population and the substantial role played by car manufacturing in the country's industrialization process contributed to the increase in car ownership. ${ }^{2}$ Between 1970 and 1990, while Mexican population grew 57\%, car ownership (including taxis) increased by a factor of 3.5 from 24 to 84 cars per 1000 persons. The 1990 per capita level was near the Brazilian level, but much lower than in industrialized countries such as the U.S. (600) or France (410) (Schipper et al. 1993).

Growth in car ownership was slowed by the economic recession of 1982-1988. Between 1970 and 1983, the car stock grew at an average annual rate of $10.3 \%$. Growth fell to $4.1 \%$ between 1983 and 1988 , but increased to $7.7 \%$ between 1988 and 1991 . The effect of the economic recession can also be seen in the new-cars/stock ratio, which declined in the mid-1980s (Figure 4.2).

\subsubsection{Trains}

Interurban trains have accounted for a decreasing portion of passenger travel in the last two decades and are now relatively minor $(0.8 \%)$. There has been a shift from train to interurban buses due to lack of improvement and expansion of the rail system.

The Mexico City subway constitutes the principal urban train system. The subway ("El Metro") was created in 1968 and was expanded in 1977 and again in 1983. Travel increased four-fold from 1975 to 1990 , reflecting the rapid increase in the subway operating length from $37.3 \mathrm{~km}$ in 1975 to $84.5 \mathrm{~km}$ in 1983 and $141 \mathrm{~km}$ in 1990.

\subsubsection{Air travel}

Domestic air travel represented $1.6 \%$ of total travel in 1975 and $1.4 \%$ in 1990. Air travel was the mode most sensitive to changes in economic conditions. After an average annual rate of growth of $15 \%$ between 1975 and 1983, between 1983 and 1988 passenger-km decreased 18\%. Between 1988 and 1990, however, passenger air travel started growing again at an annual rate of $10 \%$.

\subsubsection{Urban and interurban passenger transportation in 1990}

There are limited data available to contrast urban and interurban passenger transportation. But since urban and interurban passenger transportation have very

\footnotetext{
${ }^{2}$ By 1970, there was substantial automobile manufacture in Mexico: $60 \%$ of each vehicle sold in Mexico was produced there. By 1980, Mexico had become a significant exporter of automotive parts, particularly to the United States (Bennett and Sharpe 1985).
} 
different objectives, it is useful to estimate them at least for one year. To do so, automobile travel has to be estimated because disaggregated data are not available.

According to the 1990 national census and car registration statistics, $70 \%$ of the private automobiles and taxis were registered in the states that have the eleven most populated cities (more than 500,000 inhabitants). From this, we assume that at least $70 \%$ of the automobiles are driven primarily in cities. To estimate the distance driven in the cities, we calculated a weighted average between car and taxis per state, assuming the same distance driven in the MCMA for these modes $(12,000 \mathrm{~km})$. Finally, we assume the same load factor (1.6 persons per vehicle) as in MCMA.

The results are presented in Table 4.2 (light trucks are not included). According to this estimation, interurban travel represents $61 \%$ of national passenger travel. As expected, automobiles are more important in the urban environment $(37.3 \%$ of total urban travel) than in the interurban one ( $29.6 \%$ of total interurban travel). In both cases buses represent the most important mode of travel with $56 \%$ and $66.5 \%$ of urban and interurban travel, respectively. Air and train represent, respectively, $2.5 \%$ and $1.3 \%$ of interurban passenger-km, and trains represent $6.6 \%$ of urban passenger-km.

\subsection{Energy Use and Intensities}

Table 4.3 shows energy use and energy intensity per passenger-km and per $\mathrm{km}$ for passenger road, rail, and air transport for 1975, 1983, and 1988. Data for 1990 are not available for buses.

\subsubsection{Automobiles}

Automobile energy use increased at an average annual rate of $6.2 \%$ between 1975 and 1983, at 5.0\% between 1983 and 1988 , and at $8.3 \%$ between 1988 and 1990 . The principal element that drove the expansior of automobile energy use was the increase in the car stock.

The energy intensity of the automobile stock steadily decreased from 491 $\mathrm{MJ} / 100 \mathrm{~km}$ in 1975 to $423 \mathrm{MJ} / 100 \mathrm{~km}$ in $1990(13.7$ to $12.8 \mathrm{lt} / 100 \mathrm{~km})$. The penetration of new, less energy-intensive cars into the stock has decreased the intensity, while rising traffic congestion in the urban areas has increased it.

The energy intensity of an average new car, as measured by a standard testing procedure, declined from 417 to $281 \mathrm{MJ} / 100 \mathrm{~km}(12$ to $8 \mathrm{lt} / 100 \mathrm{~km}$ ) between 1975 and 1990 (Figure 4.3). The impact of new cars on the stock was greater in the 1970s. Sales of new cars slowed after 1983 and the average age of cars in the stock increased from 6 years in 1970 to 11 years in 1989 (CONAE 1992c). 
The main factor causing the energy intensity of the average new car to decrease was a decline in the energy intensity of "popular" cars, which are the cheapest and smallest. This decline resulted from a growing market share for the more efficient Nissan Sentra relative to the VW "bug" (these are the only two types of popular cars). There was also some increase in efficiency of compact and luxury cars. The latter switched from eight-cylinder to six-cylinder engines.

Another factor that contributed to the intensity decline was a shift in the size mix of new car sales toward smaller cars. As shown in Figure 4.4, 72\% of the new cars sold in 1970 were "popular" and compact, while in 1990 this share was $93 \%$. This trend is different from the historical trend of the OECD countries, where bigger cars have increased their shares in the automobile market (Schipper et al. 1993).

The evolution of the Mexican automobile fleet was influenced by the difficult economic circumstances of the 1980s. In 1990, the price of the cheapest new car was around 7000 US\$, while $43 \%$ of the economically active population earns between one and two minimum monthly wages, which in 1990 meant $1400-2800$ US\$ per year (MACRO 1993). Thus, most of the population still cannot afford a private car, and most of those who can look for the cheapest models. The unequal distribution of wealth in Mexico generates a high concentration of automobile ownership in a small part of the population. In 1988, 84\% of the expenditure on new cars was concentrated in the wealthiest $10 \%$ of the population ${ }^{3}$ (Vieyra 1990) (Figure 4.5).

Contrary to the decrease of energy $/ 100 \mathrm{~km}$, automobile energy intensity per p-km remained almost constant in the 1975-88 period. Decline in load factor pushed up energy intensity, while decrease in energy use per $\mathrm{km}$ pushed it down.

\subsubsection{Buses}

Energy use by urban buses (excluding microbuses), increased at an annual rate of 3.1\% between 1975 and 1983 and at an incredible $12 \%$ per year between 1983 and 1988. The most important reason for the latter increase was the rise in fuel intensity (energy per $\mathrm{km}$ ) due probably to increasing traffic congestion and lack of bus maintenance. Between 1975 and 1983, energy use per $\mathrm{km}$ decreased from 1.7 to 1.4 $\mathrm{GJ} / 100 \mathrm{~km}$, but by $1988 \mathrm{it} \mathrm{had} \mathrm{increased} \mathrm{to} 1.9 \mathrm{GJ} / 100 \mathrm{~km}$. Energy use per $\mathrm{p}-\mathrm{km}$ fell from $0.40 \mathrm{MJ} / \mathrm{p}-\mathrm{km}$ to $0.28 \mathrm{MJ} / \mathrm{p}-\mathrm{km}$ from 1975 to 1983 , but increased to $0.55 \mathrm{MJ} / \mathrm{p}-\mathrm{km}$ in 1988. The increase after 1983 was due to the rise in energy use per $\mathrm{km}$ and also to a decrease in the load factor from 53 passengers per bus in 1983 to 34 passengers per bus in 1988. The drop in load factor was associated with the increased use of privately operated microbuses and collective taxis.

\footnotetext{
${ }^{3}$ Since the wealthy purchase very expensive cars, Figure 4.4 overstates the differences in car ownership among income classes, but this difference is nonetheless great.
} 
Interurban bus energy demand grew at an annual rate of $5.6 \%$ between 1975 and 1983 and $4.3 \%$ between 1983 and 1988. Energy use per $\mathrm{km}$ decreased from 2.2 $\mathrm{GJ} / 100 \mathrm{~km}$ in 1975 to $1.8 \mathrm{GJ} / 100 \mathrm{~km}$ in 1983 , and then rose slightly to $1.9 \mathrm{GJ} / 100 \mathrm{~km}$ in 1988. Energy intensity per p-km foillowed a similar pattern.

\subsubsection{Other}

Energy use for air travel (including fuel loaded in Mexico for international flights) nearly doubled from 1975 to 1983 , was stagnant until 1988, and increased rapidly thereafter. The energy intensity is uncertain due to lack of appropriate data on p-km for international flights.

Urban train energy use increased from 1.3 to $2.7 \mathrm{PJ}$, reflecting the rising use of the Mexico City subway. It accounts for around $92 \%$ of urban rail energy use; the rest is divided between the subway of Monterrey and the light train of Guadalajara.

Interurban train energy use increased at an annual rate of $5 \%$ during the two periods. However, energy intensity increased from $0.75 \mathrm{MJ} / \mathrm{p}-\mathrm{km}$ in 1975 to 1.04 $\mathrm{MJ} / \mathrm{p}-\mathrm{km}$ in 1988 , due to a decrease in load factor.

\section{FREIGHT TRANSPORT}

\subsection{Activity and Structure}

The standard indicator of freight transport is tonne-km, which measures the weight of freight and the distance it is moved. Table 5.1 shows freight movement by ships, trains and interurban heavy trucks. Tonne-km data are not available for urban trucks and for light trucks (including vans). In 1990, these represented around $10 \%$ and $84 \%$ of the total truck stock, respectively, but accounted for a much smaller percentage of total tonne-km.

For interurban heavy trucks, tonne-km increased at an average annual rate of $7.4 \%$ between 1975 and 1983 . Economic recession drove the rate of growth down to $1.8 \%$ between 1983 and 1988 . However, the new period of economic growth in 1989-90 saw a huge rise in tonne-km of $23 \%$ per year.

During the last two decades, the overall truck fleet has shifted toward lighter trucks. Although there are no registration data available on light trucks (which include vans and small buses), it is evident that their number has increased rapidly (Figure 5.2). In 1975 the number of new light trucks sold was 58,000; sales increased to 147,000 by 1991. In 1971, heavy and medium trucks represented around $27 \%$ of the sales of new trucks. By 1988, this share had decreased to only $5 \%$. By 1990, the share of heavy and medium trucks rebounded to $8 \%$ (Figure 5.1). 
The average age of trucks has been around 8 years during the whole period. In the case of heavy trucks, the decrease in sales of new vehicles resulted in an increase in the average age from 6 years in 1970 to 11 years in 1988.

Ship freight transport (domestic and international) grew at a $10 \%$ annual rate from 1975 to 1983 , but decreased by $18 \%$ from 1983 to 1990 . The fall could be explained by the economic recession and by the decrease in oil exports (Bazan 1988).

Freight train tonne-km increased 27\% from 1975 to 1983 , but decreased $14 \%$ between 1983 and 1990, reflecting economic conditions and the decline in importance of rail in favor of road transportation. Consequently, freight train energy use declined.

\subsection{Energy Use and Intensities}

Energy use for freight transportation represented about $42 \%$ of transport energy use in 1975 , but its share decreased to $35 \%$ in 1988 due to economic stagnation and growth in passenger travel. It is difficult to disaggregate energy use in freight transport into different modes due to lack of data on road transport, which accounts for aroind $75 \%$ of total freight movement.

Table 5.2 shows energy use and intensities for interurban trucks, ships and trains. For simplicity, we assume that all the diesel used by trucks was used by interurban trucks.

Interurban truck energy use increased at an annual rate of $5.5 \%$ between 1975 and 1983, but from 1983 to 1988 it decreased in response to the recession. The estimated energy intensity decreased steadily from $2.5 \mathrm{MJ} / \mathrm{t}-\mathrm{km}$ in 1975 to $1.8 \mathrm{MJ} / \mathrm{t}-\mathrm{km}$ in 1988 .

Energy use for freight transport by train increased at an annual rate of 4.7\% between 1975 and 1983 but decreased slightly from 1983 to 1988 due to the economic recession. Freight rail energy intensity increased from $0.43 \mathrm{MJ} / \mathrm{t}-\mathrm{km}$ in 1975 to 0.64 $\mathrm{MJ} / \mathrm{t}-\mathrm{km}$ in 1983 and $0.73 \mathrm{MJ} / \mathrm{t}-\mathrm{km}$ in 1990 . This increase was due to the fall in the load factor from 11,080 tonnes in 1975 to only 8,160 tonnes in 1990 (Informe de Gobierno 1992).

Ship energy use increased at an annual rate of around 5\% between 1975 and 1988 , but rose more rapidly after 1988 . The average load factor decreased, however, resulting in a large increase in energy intensity. In 1975 ship energy use per t-km was $0.51 \mathrm{MJ}$, while in 1990 it reached 1.41 MJ. 


\section{ENERGY PRICES}

Transport fuel prices in Mexico are set by the Mexican government (Secretaria de Hacienda y Crédito Público or recently by the Secretaria de Programación). After the nationalization of the petroleum companies (1938) and until the 1970s, relatively stable prices were maintained due to a policy of state protection of indigenous development. After 1980, Mexican prices started growing due to changes in the international price of oil and decrease of public subsidies to PEMEX (due in part to the debt crisis).

As shown in Figure 6.1, real prices of gasoline and diesel were relatively stable between 1970 and 1978 (INEGI 1981, 1990 for Mexico). The first major increase in gasoline prices took place in 1980, just in the middle of the "oil boom." From 1979 to 1982 the real gasoline price grew by $170 \%$. It maintained an average annual rate of growth near 4\% until 1987. In 1986-87 inflation rose above $100 \%$, and the government froze fuel prices. From 1987 to 1988, the real price of gasoline and diesel fell by more than 50\%. In 1988 and 1990, the price of gasoline was constant and diesel prices decreased.

From 1970 until the mid 1980s, Mexican gasoline and (especially) diesel prices were lower than comparable prices in the U.S. due to price controls. When U.S. prices declined in 1986 in connection with lower world oil prices, however, prices in Mexico rose sharply, and climbed further in 1987. After the sharp decline in Mexican prices in 1988, prices in the two countries were relatively close.

\section{TRANSPORTATION IN THE MEXICO CITY METROPOLITAN AREA}

The Mexico City Metropolitan Area (MCMA) constitutes one of the largest urban centers in the world. Its 16 million inhabitants comprise $18 \%$ of Mexico's population and $25 \%$ of the economically active population. ${ }^{4}$ It contributes to $36 \%$ of the nation's GDP (PICCA 1992). With an area of $1,250 \mathrm{~km}^{2}$, the jurisdiction of the MCMA includes the Federal District $\left(650 \mathrm{~km}^{2}\right)$ and 17 municipalities in the State of Mexico. The built-up area that surrounds the MCMA grew ten-fold between 1970 and 1988 (Delgado 1988) and now embraces $7,860 \mathrm{~km}^{2}$.

The Federal District (D.F.) is Mexico's political and administrative center and represents the most important economic focus of the nation. This concentration has attracted millions of people from the countryside to the MCMA. In 1988, 55\% of the MCMA population growth was derived from natural increase (births in the MCMA) and 45\% was through migration (Imaz 1992).

\footnotetext{
4 According to the 1990 census. Some analysis believe the census result understates the actual problem.
} 
In 1992, final energy demand in the MCMA was $481 \mathrm{PJ}$, which represented $17 \%$ of the nation's final demand for 1991. About 54\% of the MCMA final energy demand was for transportation (Figure 7.1).

Currently, the MCMA has 1,371 kilometers of primary roads, $290 \mathrm{~km}$ of high priority avenues or expressways, and $950 \mathrm{~km}$ of main roads. The State of Mexico, in which the MCMA is located, has $949 \mathrm{~km}$ of roads of which $48 \mathrm{~km}$ are urban expressways, $597 \mathrm{~km}$ are primary roads, $46 \mathrm{~km}$, inter-urban limited access highways, and $258 \mathrm{~km}$ are interurban roads (DDF 1992).

In spite of the significant infrastructure, roads are usually congested by vehicles during peak hours (from 7 A.M. to 10 A.M, from 2 P.M to 4 P.M.). In recent years there has also been increasing congestion in the evenings. Velocity is around $26 \mathrm{~km} / \mathrm{hr}$ in an average day. In peak hours it falls to $7 \mathrm{~km} / \mathrm{hr}$ (CONAE 1992b).

\subsection{Passenger Transportation}

The government has provided stimulus for both private and public transportation modes to satisfy the travel demand of the rapidly growing MCMA. Public transportation was encouraged by the creation of the state-owned Metro system (subway) in 1968. Nationalization of the bus system in the D.F. in 1981 was intended to improved service. Service did in fact improve for several years, but the government's budget problems eventually led to a deterioration in service.

At the end of the 1970s, there were major public investments in road construction which encouraged the use of private cars. In 1979, 17 new avenues ("ejes viales") - with five lanes in one direction - began operation (Navarro 1988). In 1980 another $97 \mathrm{~km}$ of "ejes viales" were added to the initial $115 \mathrm{~km}$. At the beginning of the operation of the "ejes viales," two of the lanes were designed for public buses, one in the direction of the automobile flow, and the other in the opposite direction. A few years later, an increase in the congestion, as well as an increase in accidents (due to the flow in different direction), resulted in a change the public bus lanes to normal flow lanes.

In 1982, the Mexican government reduced its investments in public transportation due to the economic recession. Thereafter, the continued expansion of the city and an insufficient development of public mass transportation resulted in an increased use of private cars, taxis, collective taxis and microbuses.

Lack of passenger-km data makes it impossible to precisely evaluate the historical trend of changes in activity and structure. Data on p-km in the MCMA are available only for 1990. However, surveys for 1983 (Lizt 1988) and 1990 (DDF 1992) give the number of passenger-trips per day by mode.

The 1983 COVITUR study (Lizt 1988) indicated that $50 \%$ of all daily journeys 
undertaken in the MCMA were for work, 35\% were for school, and $8 \%$ were for shopping and recreation. In the U.S., $23 \%$ of the personal trips are for work, $36 \%$ for family and personal business, $12 \%$ for civic, religious and education, $28 \%$ for social and recreational activities, and $2 \%$ for other purposes (U.S. DOT 1990). The big differences between the U.S. figures and the MCMA are the higher number for education in Mexico and the higher number for recreational activities in the U.S. The higher number for trips to school is related to the large share that youth and children have in the MCMA population. The higher number for recreational activities probably has to do with the higher incomes in the U.S.

The same study also shows the number of daily joumeys undertaken in the MCMA in 1983 by means of transportation, including walking (Table 7.1). Travel by bus accounted for the major proportion of daily journeys, followed by walking.

The most important types of transportation in the MCMA include the Metro (subway), buses, trolleys, light train, collective taxis, private taxis and private cars. Figure 7.2 shows changes in the share of passenger trips per day ( $\mathrm{p}-\mathrm{t} / \mathrm{d})$ for all the modes for 1983 and 1990. Between these years $p-t / d$ increased at an annual rate of growth of $10.6 \%$, compared to the $2.5 \%$ annual rate of growth of the MCMA population.

Metro. The Metro, whose official name is the Collective Transport System, is state-owned. In 1990 the Metro included 8 lines and $140 \mathrm{~km}$ of track, which is $65 \%$ more than in 1983. During the last two decades, the Metro service grew from 0.9 to 3.6 million p-t/d. However, the Metro system did not grow at the same rate as the passenger demand for travel, and hence, between 1983 and 1990 the Metro share of MCMA p-t/d decreased from $23 \%$ to $15 \%$.

Urban buses. Urban buses are divided into two types: those that circulate in the Federal District and those that circulate in the state of Mexico. In 1990, Ruta 100 (the state-owned bus system operating in the D.F.) ran 210 routes with 3,500 buses. The bus system in the State of Mexico consisted of 67 private companies, or "permisionarios," which circulated in 345 routes (18\% of which have as their final destination the eight Metro lines at the border of the Federal District and the State of Mexico). In 1983 urban buses (both R-100 and State of Mexico system) represented the most important means of travel in the MCMA with 33\% of total $p-t / d$. By 1990, their share of $p-t / d$ was reduced to $19.5 \%$ as the slightly more expensive but faster collective taxis and microbuses came into vogue.

Trolley buses. The trolleys are operated by the Electrical Transport System (STE) on 35 routes in the Federal District. With 450 units, the STE represented in 1990 just $2 \%$ of total p-t/d, almost the same as in 1983 (DDF 1992).

Trams and light train. Between 1985 and 1988 most of the trams that circulated in the Federal District were removed. One of the old tram lines in the South of the 
Federal District was replaced by a new light train (Legorreta 1988). According to the COVITUR survey (Lizt 1988) and data from the DDF (1992), in 1983 trams generated around 55 thousand $p-t / d$. In 1990 , they generated just 20 thousand $p-t / d$, less than $1 \%$ of the total.

Collective taxis and microbuses. Stagnation of urban and suburban public bus supply led to an increase in the use of low capacity private vehicles with higher tariffs than public buses. Between 1983 and 1990 the number of collective taxis increased and the traditional pattern of large cars carrying a maximum of six passengers along a few set routes was overtaken by a widespread use of Volkswagen vans ("combis") carrying 10 to 11 people. More recently, larger microbuses (with $40 \%$ less capacity than the traditional urban buses) have appeared on many important routes. 5

Before 1984 most collective taxis were operated by independent drivers without official supervision. In that year the MCMA government started a process of regularization of routes and tariffs, which allowed greater control over the number of taxis, and also facilitated a renovation program in the early 1990s. At the end of 1988 most of the collective taxis were officially registered (Legorreta 1988).

In $1990,47,500$ combis and 8,080 microbuses were circulating within the MCMA. Between 1983 and $1990, \mathrm{p}-\mathrm{t} / \mathrm{d}$ increased from 1.8 to 11.1 million in the case of collective taxis and from none to 3.3 million in the case of microbuses. This expansion happened irregularly depending on the city's geography, generating car loads of about half of a vehicle's capacity during non peak hours. The share of $p-t / d$ of collective taxis and microbuses increased from $11.2 \%$ to $28.2 \%$ and from none to $8.5 \%$ respectively.

Taxis. The number of taxi p-t/d increased between 1983 and 1990 from 154 thousand to 1.5 million, representing $1 \%$ and $3.8 \%$ of the total respectively. The expansion of the taxi fleet was also a response to the lack of public buses. The increased domestic production of VW "bugs", also helped increase the taxi fleet. The fares of MCMA taxis are about ten times more expensive than the collective taxis; however, they still are affordable for a some parts of the population.

Private cars. According to official data, 2.6 million cars were registered in the MCMA in 1990. Other sources estimate that between 3 and 3.5 million cars are in use in the MCMA (these include cars registered outside the MCMA) (Legorreta 1988). Using official data, the car fleet increased at an annual rate of 5.8\% per year between 1975 and 1990. Between 1983 and 1990, automobile $p-t / d$ increased from 4.3 to 9.1 million. Yet the increase in microbuses and collective taxis was so big that the private car share of total $\mathrm{p}-\mathrm{t} / \mathrm{d}$ decreased from $27 \%$ to $23 \%$. Although private vehicles

5 At the end of 1992 the Federal District government prohibited the use of combis as a collective mode of transportation in an effort to reduce air pollution and congestion. In the State of Mexico the "combis" have not been removed from circulation. 
represented $23 \%$ of total $p-t / d$, they accounted for $96 \%$ of all passenger vehicles on the road of the MCMA, clearly showing their relevance to traffic congestion.

\subsubsection{Activity and intensity in 1990 in the MCMA}

In 1990, the total number of passenger-km in the MCMA was 100 billion, which represented $15 \%$ of the national $\mathrm{p}-\mathrm{km}$. The $\mathrm{p}-\mathrm{km}$ were distributed as follows: automobiles $33 \%$, taxis $2.9 \%$, buses $17.6 \%$, collective taxis $20.9 \%$, microbuses $6.9 \%$, Metro 17.7\%, and trams and trolleys 1.3\% (DDF 1992) (Figure 7.3).

Table 7.2 shows the estimated energy intensity for each of the transportation modes in 1990. Private automobiles have the highest energy intensity (per $p-k m$ ), followed by taxis. The low values are due to low load factors (1.6 and 1.7 respectively) and the large share of old cars in the automobile fleet. The Metro is the most efficient mode with 95\% lower final energy intensity (and $85 \%$ lower primary energy intensity) than private cars. Ruta 100 buses use half as much energy per p-km as the collective taxis (combis). Ruta 100 buses are less energy-intensive than those in the State of Mexico due to the lower load factors of the latter ( 40 and 20 persons per bus, respectively).

In 1990, the estimated fuel intensity of the MCMA private automobiles and taxis was $16.7 \mathrm{lt} / 100 \mathrm{~km}$, which was $20 \%$ higher than the national average. The higher value is due to both higher fuel consumption in congested traffic and to the older vintage of the MCMA's automobiles.

\subsection{Freight Transportation}

Lack of data makes it impossible to analyze either the trends or the current situation of MCMA freight transportation. According to a 1981 study, $35 \%$ of total tonnes transported in Mexico were moved towards the MCMA; half of this was consumed within the MCMA (Camarena 1987b).

In 1990 there were 196,000 gasoline-fueled trucks registered in the MCMA and 60,000 diesel-powered trucks. According to CONAE (1992a), freight transportation accounted for 23\% of transport energy use within the MCMA in 1988 and for $28 \%$ of total vehicle emissions.

\subsection{Environmental Problems in the MCMA}

Air pollution from vehicles is a serious problem within the MCMA. The 2,249meter elevation exacerbates the air pollution in the MCMA valley. The $\mathrm{kW}$ atmospheric pressure and consequent lower amount of oxygen cause poor fuel combustion (a cubic meter of air in Mexico City contains $23 \%$ less oxygen than at sea level) (Legorreta 
1989). Low atmospheric pressure also increases volatile $\mathrm{HC}$ emissions from the vehicles. The high mountains that surround the city, along with a lack of wind (seven months of the year the region maintains winds of less than $1.5 \mathrm{~m} / \mathrm{s}$ ), account for poor dispersion of emissions and long periods (100 days/year) of thermal inversions.

The most serious air quality problem in the MCMA is the high concentration of ozone (formed by the reaction of hydrocarbons, nitrogen oxides, and ultraviolet radiation). From 1988 to 1991 , winter ozone concentrations in the MCMA exceeded the standards more than $50 \%$ of the time (Legorreta 1989). Emissions of sulfur dioxide $\left(\mathrm{SO}_{2}\right)$, carbon monoxide $(\mathrm{CO})$, and lead $(\mathrm{Pb})$ are also important.

Vehicles account for around $75 \%$ of the total atmospheric emissions expelled into the atmosphere in the MCMA, and private cars emit more than half of the total vehicle emissions (DDF 1992, Legorreta 1988). Figure 7.4 shows the contribution of sources according to a DDF study that used a model called MOBILE-MCMA. ${ }^{6}$ Emissions from passenger transport in the MCMA in 1991 amounted to 183 thousand tons of HC, 1800 thousand tons of $\mathrm{CO}$, and 50 thousand tons of $\mathrm{NO}_{\mathrm{x}}{ }^{7}$. Private cars account for around $70 \%$ of the $\mathrm{HC}$ and $\mathrm{CO}$ emissions. Additionally, heavy trucks were estimated to produce 46 thousand tons of $\mathrm{HC}, 375$ thousand tons of $\mathrm{CO}$ and 46 thousand tons of $\mathrm{NO}_{\mathrm{x}}$.

\subsection{Transportation Policies in the MCMA}

Reducing air pollution in the MCMA has been an important goal of government transportation policies in recent years. Seven main policies to reduce emissions from mobile sources have been instituted in the MCMA between 1988 and 1991: (1) Introduction of unleaded gasoline (Magna-sin), (2) Emission standards and periodic inspections of automobiles, (3) "A day without a car" program, (4) Promotion of LPG and natural gas as alternative fuels, (5) Replacement of older taxis, (6) Expansion of the Metro system and, (7) Fleet renovation of Ruta 100's bus system. ${ }^{8}$

Introduction of unleaded gasoline. After September 1990 a new gasoline (Magna-sin) with 87 octane and minimal lead content (less than 0.01 grams per gallon) was mandatory for all the 1991 models (DDF 1992). At the same time, the lead content of the regular gasoline was reduced. According to DDF (1992), the introduction of these new gasolines reduced the lead concentration in the MCMA atmosphere to the international norms.

\footnotetext{
${ }^{6}$ MOBILE-MCMA is a model that calculates emissions by mode, taking into account the average velocity. It uses U.S. EPA emission coefficients adjusted to the MCMA conditions.

7 This estimate does not include emissions from evaporation of non-running vehicles, unusual traffic congestion, school and private buses, local and interstate cargo trucks, and interurban private cars.

8 As mentioned before, in 1992 an additional policy was implemented: the circulation of combis in the Federal District was prohibited. Combis were substituted by microbuses.
} 
Emission standards. The establishment of exhaust emission standards and periodic inspection of automobiles has been one of the main policies for reducing emissions. Beginning in 1989, every car registered in the MCMA was required to pass an annual emission test; in 1991 it became a biannual one. Each car has to have a visible official sticker that shows it has passed the emission test. The consequences of this policy are not evident, however, since ozone concentrations have increased in the MCMA (CECODES 1991, DDF 1992). Evasion of the emissions test by the illegal sale of the emission sticker occurs, but the extent is unknown.

"A day without a car." This policy prohibits the use of personal vehicles on one workweek day (from 6 A.M. to 10 P.M.) depending on license plate numbers. The policy was implemented in January 1989 and its intent was to reduce gasoline use and the consequent emissions by $20 \%$. Nevertheless, decrease in prices of some of the most popular vehicles (Volkswagen "bug") and low interest loans promoted the ownership of a second car, which allowed many people to evade the policy. In addition, demand increased for both taxis and collective taxis.

Replacement of old taxis. As of 1993, all taxis in use in the MCMA must be of 1986 or later vintage and all collective taxis must be of 1984 or later vintage. Taxi owners had the opportunity to receive low-interest loans for the purchase of a new car. This program promoted fuel efficiency and reduced emissions by almost $90 \%$ for each taxi replaced (DDF 1992). However, most of the old replaced vehicles (that worked as taxis) remain in use as private cars. Many of the replaced vehicles are older VWs with low fuel efficiency (less than $10 \mathrm{~km} /$ liter) ${ }^{9}$ and no fuel injection.

Promotion of LPG and natural gas. LPG has been used in Mexico for private cars and light trucks since the 1970s. In 1991, the government encouraged switching from gasoline to either LPG or natural gas by letting these vehicles circulate five rather than four days a week. The switch from gasoline to gas does not improve fuel efficiency but does reduce emissions. ${ }^{10}$ In 1992, less than $1 \%$ of the MCMA vehicle fleet or about 4500 vehicles switched to LPG. A large scale switch to natural gas would require imports of this fuel, since Mexico's natural gas reserves are declining.

Metro. An expansion of the Metro was started in 1990. Four new routes totalling about $40 \mathrm{~km}$ are planned to be ready in 1994 . Also planned is a new light train route of about $17 \mathrm{~km}$.

Ruta 100 Fleet Renovation. After March 1991, most of the Ruta 100 engines were replaced with newer ones. In addition, a maintenance program was instituted to control

9 Some of the new taxis are Nissan Sentras: these have an average fuel efficiency of $16 \mathrm{~km} / \mathrm{lt}$. However, the cheaper price of VWs promotes their sale. (Personal communication with Ing. Arenas, CONAE and Ing. Lacy, DDF.)

10 The vehicle must be equipped with a catalytic converter to reduce HC emissions. 
emissions (PICCA 1992).

\section{MAJOR CONCLUSIONS}

The transport sector in Mexico is responsible for around $40 \%$ of total final energy use, but for $65 \%$ of total oil consumption. The economic recession in the 1980s slowed the growth of energy use for both passenger and freight transportation. Energy use accelerated after 1988, however, rising much faster than GDP.

Road transportation is by far the most important type of both freight and passenger transportation, representing around $90 \%$ of $\mathrm{p}-\mathrm{km}$, ton- $\mathrm{km}$, and energy use. Increasing fuel use by automobiles and trucks has been primarily responsible for the rapid growth in transport energy demand in recent years.

The automobile fleet has increased from 1 million in 1970 to over 7 million in 1991. Despite the growing use of automobiles, public transportation (mainly buses) has continued to dominate passenger travel in Mexico. The share of interurban buses in total travel increased over the last two decades, but the share of urban buses has started to fall due to increased use of collective taxis and microbuses.

Small cars dominate the Mexican car fleet. The share of "popular" cars (subcompacts) in new car sales rose from $44 \%$ in 1970 to $65 \%$ in 1983, and then fell somewhat to $58 \%$ in 1990 . Fleet-average automobile energy use per $\mathrm{km}$ declined steadily between 1975 and 1990 due to a large improvement in the average fuel economy of new cars. This improvement was caused mainly by a shift within the popular car class to a more fuel-efficient model.

Energy use per $\mathrm{km}$ for interurban and urban buses declined somewhat between 1975 and 1983, but the fuel intensity of urban buses appears to have risen considerably between 1983 and 1988 . The increase could be due to greater traffic congestion, as well as inadequate maintenance due to lack of funds for the bus systems. The increase in energy use per $\mathrm{p}$ - $\mathrm{km}$ for urban buses was even greater due to deterioration in the load factor as large buses lost customers to microbuses and collective taxis.

In the Mexico City Metropolitan Area (MCMA), population increase has put intense pressure on transportation services. Inadequate development of the mass transport system has led to an increase in use of low-capacity vehicles such as collective taxis, taxis, and microbuses. These modes, operated by private owners, have overtaken most of the bus routes, increasing congestion. Such low-capacity vehicles can be an important mode of transportation for narrow streets or low-demand routes, but for high-demand routes and wide avenues, a high-capacity mode is much more efficient and reduces congestion. 
Growth in travel in general and in use of light vehicles in particular has increased air pollution problems in the MCMA. Vehicle emissions represent around $70 \%$ of the total emissions to the atmosphere of the MCMA, and private cars emit more than half of the total emissions coming from mobile sources.

The government implemented various transportation policies in the MCMA to decrease pollution levels. Some of them have been positive, such as the implementation of emission standards and regular inspection of automobiles, construction of new Metro routes, renovation of buses, and mandating catalytic converters in new cars. The removal of the trolley and trams may have contributed to higher pollution, however.

Some policiej did not achieve their goal of reducing emissions because other measures created a contrary effect. For example, the "one day without a car" policy implemented in January 1989 was not successful because a decrease in the price of the VW "bug" and low-interest loans to buy new and used cars encouraged purchase of second cars, which could then be used to evade the policy. The taxi-renovation program promoted fuel efficiency and reduced emissions, but most of the replaced vehicles (that worked as taxis) remained in use as private cars.

\subsection{Policy Implications}

The trends of the 1988-91 period suggest that continuation of economic reforms and implementation of NAFTA are likely to lead to considerable growth in oil consumption for transportation in Mexico. The automobile fleet grew rapidly in the 198891 period as incomes rose, and rising traffic congestion worsened fleet-average fuel economy. Among other types of urban passenger transport, less energy-efficient modes such as taxis and microbuses have taken passengers from large buses. Truck freight transport already rose rapidly in the $1988-91$ period, and increase in trade between the U.S. and Mexico will bring further growth. Unless the government takes steps to manage transportation fuel use, domestic oil consumption could rise at a rapid rate, draining the country's resources, and rising traffic congestion and urban air pollution will bring economic and health burdens.

In the MCMA in particular, strong government intervention has to be taken in the MCMA if pollution emissions are to be reduced. Lower-polluting (and more fuelefficient) public transportation modes have to supply more of the increasing demand for travel services. A major effort must be made to promote the shift of the private car fleet towards more efficient automobiles with fuel injection and catalytic converters. More intense efforts to promote cleaner fuels or electric vehicles would also be beneficial. 


\section{APPENDIX: DATA SOURCES}

The data presented in this report were gathered from several sources. Aggregate energy use is from the annual national energy balances (SEMIP 1965-1985, 1991), in which transportation energy use is split by fuels since 1965, and by fuel and modes (road, rail, water, and air) since 1986.

Energy intensity per kilometer for various modes is taken from CONAE (1992c). Number of vehicles for each mode, as well as passenger-km and tonne-km for interurban buses and trucks respectively, are from INEGI (1980 and 1991). Passenger-km and tonne-km for interurban train and air is from "Informe de Gobierno" (1992). There are no data on passenger and tonne-km for light trucks (which include vans and microbuses).

Urban bus passenger-km is from CONAE (1992c), which is based on several surveys (1975: Estudio Comision Energeticos, 1983: Estudio ICATEC/ PEMEX, 1988: Estudio SEMIP/CEE).

Automobile passenger-km is difficult to estimate. Annual distance driven per car and taxi for 1975, 1983 and 1988 are from CONAE (1992c); we adjusted the 1988 data on distance driven per taxi due to its extremely high value. Load factor data reported by CONAE seem to be too low. CONAE reports 1.6 persons per car in 1983, which is lower than in US (1.7), UK (1.78) and France (1.85) (Schipper and Meyers 1992). We decided to use the same load factor nationally as reported by Ferrando (1987) and DDF (1992) for the MCMA, which is 2.0, 1.8 and 1.6 persons per automobile for 1975, 1983 and 1990 respectively. 


\section{REFERENCES}

Banco de Mexico. 1986. Informe Anual. Mexico DF.

Bennett, D., \& Sharpe, E. 1985. Transnational Corporations versus the State. Princeton University Press. Princeton N.J.

Bazan, G. 1988. Transporte y Energia: Consumo de Energia en el Sector Transporte. Coleccion Popular. FCE. Mexico.

Camarena, M. 1987a. Transporte, Consumo Energetico y Organizacion de las actividades, in Racionalidad Energetica en el Sector Transporte. Programa Universitario de Energia-Universidad Nacional Autonoma de Mexico. Mexico DF.

Camarena, M. 1987b. El Transporte de Carga en el Valle de Mexico, Instituto de Investigaciones Sociales- GV editores.

Comision Nacinal de Ahorro de Energia (CONAE)- Secretaria de Energia, Minas e Industria Parastatal (SEMIP). 1992a. Programa Integral de Transporte. Mexico DF.

CONAE-SEMIP. 1992b. Programa Integral contra la Contaminacion Atmosferica en la Zona Metropolitana de la Ciudad de Mexico: Acciones Inmediatas. Mexico DF.

CONAE-SEMIP. 1992c. El Consumo de Energia en el Sector Transporte: Preseleccion de Acciones para el Ahorro de Energia. Mexico DF.

Darbera, R. 1993. Deregulation of Urban Transport in Chile: What have we learned in the decade 1979-1989?. Transport Reviews, Vol.13, No. 1, pp 45-59.

DDF. 1992a. Coordinacion de Proyectos Ambientales. Informe Interno. Mexico DF.

DDF. 1992b. Programa para el Uso del Gas LP y Gas Natural Comprimido en el Autotransporte Publico y Consecionado. Comision Metropolitana para la Prevencion de la Contaminacion Ambiental en el Valle de Mexico.

Delgado, J. 1988. El patron de Ocupacion Territorial en la Ciudad de Mexico al año 2000, in Estructura Territorial de la Ciudad de Mexico, Terrazas $O$ and Preial E. (ed). DDF-Plaza y Valdez. Mexico.

Ferrando, G. 1987. Participacion de los Sitemas de Transporte Publico Urbano. Programa Universitario de Energia-Universidad Nacional Autonoma de Mexico. Mexico DF.

Gutierrez, A. 1987. El Transporte Ferroviario: Posibilidades de Ahorro Energetico in Racionalidad Energetica en el Sector Transporte. Programa Universitario de Energia-UNAM 
Mexico DF.

Imaz, M. 1992. El Habitat Urbano de la Ciudad de Mexico. Tesis Licenciatura. UNAM. Mexico DF.

International Energy Agency (IEA). 1991. Energy Prices and Taxes. IEA Statistics. Paris.

International Monetary Fund. 1991. International Financial Statistics. Washington, DC.

Instituto Nacional de Estadistica Geografia e Informatica (INEGI). 1980. La Industria Automotriz em Mexico. Mexico DF.

INEGI. 1990. La Industria Automotriz em Mexico. Mexico DF.

INEGI. 1991. La Industria Petrolera en Mexico. Mexico DF.

Islas, V. 1992. Estructura y Desarrollo del Sector transporte en Mexico. Colegio de mexico. Mexico DF.

Legorreta, J. 1988. El Transporte Publico Automotor en la Ciudad de Mexico y sus efectos en la Contaminacion Atmosferica, in El Medio Ambiente y Calidad de Vida, Legorreta, Puentes (ed). DDF-PyV. Mexico.

Lizt Mendoza, S. 1988. La Ciudad de Mexico : Caracteristicas del Transporte Urbano, in Grandes Problemas de la Ciudad de Mexico. Benitez, Benigno (ed). DDF-PyV. Mexico.

Nacional Financiera. 1984. La Economia Mexicana en Cifras. Nacional Financiera, Mexico DF.

Navarro, B. 1988. Sistemas de Transporte y Metropolizacion en la Ciudad de Mexico, in Racionalidad Energetica en el Sector Transporte. Programa Universitario de Energia-Universidad Nacional Autonoma de Mexico. Mexico DF.

Rodriguez, G. 1992. Los Dos Mexicos: la pobreza de muchos y el privilegio de pocos. El Financiero. Mexico. 20 de julio.

Programa Integral de Control de la Contaminacion Ambiental. 1992. Informe Anual. Mexico DF.

Informe de Gobierno. 1992. Mexico DF.

Sathaye, J., \& Ketoff, A., ed. 1991. CO-2 Emissions from Major Developing Countries: Better Understanding the Role of Energy in the Long Term. Vol I. --Summary. LBL-29507. Berkeley CA. Lawrence Berkeley Laboratory. 
Schipper, L., Steiner, R., \& Meyers, S. 1993. "Trends in Transportation Energy Use, 19701988: An International Perspective," in Transportation and Global Climate Change, D. Greene and D. Santini (eds.). American Council for an Energy-Efficient Economy, Washinton, D.C.

SEMIP 1965-1984. Balances de Energia. Mexico DF.

SEMIP 1991. Balances de Energia. Mexico DF.

Vieyra, A. 1992. Consumo de Energia de los Autos Particulares en Mexico. SEMIP-CONAE. Mexico.

Ward, P. 1990. Mexico City: The production and reproduction of a urban environment. G.K. Hall \& Co. Boston, Mass.

World Bank. 1991. World Tables 1991. The Johns Hopkins University Press. Baltimore and London. 
Table 3.1

Transportation Energy Use by Mode and by Fuel Shares of Final Energy

\begin{tabular}{|l|r|r|r|r|}
\hline & 1975 & 1983 & 1988 & 1990 \\
\hline TOTAL (PJ) & 645.85 & 1026.6 & 1128.7 & 1342.4 \\
& $100.0 \%$ & $100.0 \%$ & $100.0 \%$ & $100.0 \%$ \\
Cars and taxis & $37.5 \%$ & $38.3 \%$ & $44.8 \%$ & $44.5 \%$ \\
Gasoline & $36.5 \%$ & $37.6 \%$ & $43.8 \%$ & $43.5 \%$ \\
LPG & $1.0 \%$ & $0.7 \%$ & $1.0 \%$ & $1.0 \%$ \\
& & & & \\
Buses & $11.1 \%$ & $10.1 \%$ & $13.5 \%$ & n.a. \\
Gasoline & $4.0 \%$ & $3.1 \%$ & $5.0 \%$ & n.a. \\
Diesel & $6.7 \%$ & $6.5 \%$ & $7.5 \%$ & n.a. \\
LPG & $0.4 \%$ & $0.5 \%$ & $1.1 \%$ & n.a. \\
Trucks & & & & \\
Gasoline & $39.4 \%$ & $40.9 \%$ & $32.2 \%$ & n.a. \\
Diesel & $18.1 \%$ & $19.9 \%$ & $14.4 \%$ & n.a. \\
LPG & $21.1 \%$ & $20.6 \%$ & $16.9 \%$ & n.a. \\
Ships & $0.2 \%$ & $0.4 \%$ & $1.0 \%$ & n.a. \\
Diesel & & & & \\
Fuel Oil & $1.7 \%$ & $1.7 \%$ & $1.9 \%$ & $2.0 \%$ \\
Airplanes & $0.8 \%$ & $1.2 \%$ & $1.5 \%$ & $1.6 \%$ \\
Gasoline & $0.9 \%$ & $0.5 \%$ & $0.4 \%$ & $0.4 \%$ \\
Jet Fuel & & & & \\
Trains & $5.5 \%$ & $6.0 \%$ & $5.3 \%$ & $5.8 \%$ \\
Diesel & $0.3 \%$ & $0.3 \%$ & $0.2 \%$ & $0.2 \%$ \\
Electric & $5.2 \%$ & $5.7 \%$ & $5.1 \%$ & $5.6 \%$ \\
\hline & & & & \\
& $4.6 \%$ & $2.9 \%$ & $2.3 \%$ & $2.2 \%$ \\
& $4.4 \%$ & $2.7 \%$ & $2.1 \%$ & $2.0 \%$ \\
& $0.2 \%$ & $0.2 \%$ & $0.2 \%$ & $0.2 \%$ \\
\hline
\end{tabular}

Sources: SEMIP 1975, 1990, CONAE 1990b, own estimations (see text for discussion) 
Table 4.1

Passenger Travel in Mexico by Mode"

\begin{tabular}{|l|r|r|r|r|}
\hline \multicolumn{1}{|c|}{ Modes: } & 1975 & 1983 & 1988 & 1990 \\
\hline TOTAL km (10^9) & 291.42 & 523.58 & 604.95 & 677.80 \\
Cars and Taxis & $33.0 \%$ & $29.7 \%$ & $32.6 \%$ & $32.6 \%$ \\
Interurban buses & $35.3 \%$ & $36.3 \%$ & $39.9 \%$ & $40.1 \%$ \\
Urban buses & $27.5 \%$ & $28.6 \%$ & $22.6 \%$ & $22.5 \%$ \\
Interurban Train & $1.4 \%$ & $1.1 \%$ & $0.9 \%$ & $0.8 \%$ \\
Urban Train & $1.4 \%$ & $2.5 \%$ & $2.7 \%$ & $2.6 \%$ \\
Airplane & $1.4 \%$ & $1.7 \%$ & $1.2 \%$ & $1.5 \%$ \\
Pass-km/cap (10-3) & 4.94 & 7.39 & 7.75 & 8.34 \\
\hline
\end{tabular}

- Light trucks not included

Source: CONAE, INEGI, Own estimations

Table 4.2

Urban and Interurban

Passenger Transportation (1990)*

p-km (10-9)

\begin{tabular}{|l|r|r|r|}
\hline Modes: & Urban & Interurban & Total \\
\hline Cars and Taxis & 99.4 & 121.7 & 221.1 \\
Buses & 152.0 & 271.5 & 423.5 \\
Train & 17.7 & 5.3 & 23.0 \\
Airplane & & 10.2 & 10.2 \\
TOTAL & 269.1 & 408.7 & 677.8 \\
\hline
\end{tabular}

- Light trucks not included

Source: CONAE, INEGI, Own estimations 
Table 4.3

Energy Use and Energy Intensity

Passenger Transportation *

\begin{tabular}{|c|c|c|c|c|}
\hline \multicolumn{5}{|l|}{ Modes: } \\
\hline \multicolumn{5}{|l|}{ Cars and Taxis } \\
\hline Energy use (PJ) & 235.7 & 385.5 & 494.3 & 584.2 \\
\hline MJ/100km & 490.8 & 445.7 & 425.6 & 422.8 \\
\hline MJ/p-km & 2.45 & 2.48 & 2.50 & 2.64 \\
\hline \multicolumn{5}{|l|}{ Interurban buses } \\
\hline Energy use (PJ) & 39.7 & 62.3 & 77.1 & n.a \\
\hline MJ/100km & 2186.0 & 1832.0 & 1914.0 & n.a \\
\hline MJ/p-km & 0.39 & 0.33 & 0.32 & n.a \\
\hline \multicolumn{5}{|l|}{ Urban buses } \\
\hline Energy use (PJ) & 31.5 & 41.2 & 75.4 & n.a \\
\hline $\mathrm{MJ} / 100 \mathrm{~km}$ & 1735.0 & 1446.0 & 1896.0 & n.a \\
\hline$M J / p-k m$ & 0.40 & 0.28 & 0.55 & n.a \\
\hline \multicolumn{5}{|l|}{ Urban rail } \\
\hline Energy use (PJ) & 1.3 & 1.8 & $\begin{array}{r}2.7 \\
0.5 ?\end{array}$ & $\begin{array}{r}2.7 \\
0.50\end{array}$ \\
\hline MJ/p-km & $0.46 e$ & 0.44 & 0.52 & \\
\hline $\begin{array}{l}\text { Interurban rail } \\
\text { Energy use (PJ) }\end{array}$ & 3.1 & 4.5 & 5.8 & 5.6 \\
\hline$M J / p-k m$ & 0.75 & 0.80 & 1.04 & 1.05 \\
\hline Air** & & & & \\
\hline Energy use (PJ) & 37.7 & 65.2 & 64.1 & 84.5 \\
\hline
\end{tabular}

"Microbuses and light trucks not included

- Includes fuel loaded for international flights.

Lt. gasoline $=32.9 \mathrm{MJ}$, It. diesel $=38.7 \mathrm{MJ}$

1975 urben rail is estimated since electricity was also used for trems

Electricity for urban reil does not count generation and transmission loses

Sourco: CONAE, SEMIP, own ostimations 
Table 5.1

Freight Transportation in Mexico

Tonne-Km (10^9)

\begin{tabular}{|l|r|r|r|r|}
\hline Modes: & 1975 & 1983 & 1988 & 1990 \\
\hline Interurban trucks & 55.0 & 94.3 & 102.9 & 149.6 \\
Train & 33.1 & 42.3 & 41.1 & 36.4 \\
Ship & 21.3 & 23.4 & 20.1 & 19.3 \\
Total & 109.4 & 160 & 164.1 & 205.3 \\
\hline
\end{tabular}

Sources: SEMIP 1975, 1990, CONAE 1990b, own estimations (see text for discussion)

Table 5.2

Energy Use and Energy Intensity Freight Transportation *

\begin{tabular}{|l|r|r|r|r|}
\hline Modes: & 1975 & 1983 & 1988 & 1990 \\
\hline Total, PJ & 279.5 & 437.3 & 406.6 & \\
Interurban trucks * & 136.0 & 214.9 & 186.7 & \\
Energy use, PJ & 2.47 & 2.23 & 1.8 & \\
MJ/t-km & & & & \\
Train & 14.1 & 20.5 & 21.7 & 22.4 \\
Energy use, PJ & 0.43 & 0.67 & 0.64 & 0.73 \\
MJ/t-km & 10.8 & 17.4 & 21.2 & 27.2 \\
Ship & 0.51 & 0.74 & 1.01 & 1.41 \\
Energy use, PJ & & & & \\
MJ/t-km & 118.6 & 184.5 & 177.0 & \\
Other** & & \\
Energy use, PJ &
\end{tabular}

"Assuming that all truck diesel use is for interurban trucks

" "Light trucks and urban heavy trucks

Sources: SEMIP 1975, 1990, CONAE 1990b, own estimations (see text for discussion) 
Table 7.1

Number of Daily Journeys

Undertaken in the MCMA

1983

\begin{tabular}{|l|r|r|}
\hline Modes & $\begin{array}{r}\text { trips } \\
10^{-} 6\end{array}$ & $\%$ \\
\hline Metro & 3.45 & $12.7 \%$ \\
Buses & 9.93 & $36.7 \%$ \\
Private Car & 4.30 & $15.9 \%$ \\
Collective Taxi & 1.84 & $6.8 \%$ \\
Taxi & 0.16 & $0.6 \%$ \\
Trolley & 0.28 & $1.0 \%$ \\
School bus & 0.19 & $0.7 \%$ \\
Light train & 0.59 & $2.2 \%$ \\
Motorcycle & 0.15 & $0.6 \%$ \\
Bicycle & 0.09 & $0.3 \%$ \\
Walking & 6.10 & $22.5 \%$ \\
Total & 27.08 & $100 \%$ \\
\hline
\end{tabular}

Source: Lizt 1988

For Metro: Camarena 1987

Walking trips: either more than five minutes or more than 500 meters 
Table 7.2

Passenger Transportation in the MCMA

\begin{tabular}{|c|c|c|c|c|c|c|c|c|}
\hline & Distance & Fleet & Load & $p-k m$ & share & Fuel inten & Energy use & En. Intensity \\
\hline & $\mathrm{km}\left(10^{\wedge} 3\right)$ & $\left(10^{\wedge} 6\right)$ & pers/vehi & $\left(10^{\wedge} 9\right)$ & $\%$ & it/100 km & PJ & $\mathrm{MJ} / \mathrm{p}-\mathrm{km}$ \\
\hline Metro & 131.4 & 2.2 & 60.0 & 17.7 & $17.02 \%$ & & 2.71 & 0.15 \\
\hline Bus (state of Mexico) & 91.3 & 4.0 & 20.0 & 7.3 & $7.04 \%$ & 50.0 & 6.52 & 0.89 \\
\hline R-100 & 73.0 & 3.5 & 40.0 & 10.2 & $9.85 \%$ & 50.0 & 4.56 & 0.45 \\
\hline Automobile & 8.4 & 2600.0 & 1.5 & 32.8 & $31.58 \%$ & 16.7 & 117.72 & 3.59 \\
\hline Taxi & 73.0 & 56.5 & 1.7 & 7.0 & $6.76 \%$ & 16.7 & 22.23 & 3.17 \\
\hline Combi & 73.0 & 47.5 & 6.0 & 20.8 & $20.06 \%$ & 16.7 & 18.69 & 0.90 \\
\hline \begin{tabular}{|l|} 
Troley \\
\end{tabular} & 65.7 & 0.5 & 35.0 & 1.0 & $1.00 \%$ & & & \\
\hline Tram & 73.0 & 0.0 & 45.0 & 0.0 & $0.04 \%$ & & & \\
\hline Microbus & 65.7 & 8.1 & 13.0 & 6.9 & $6.65 \%$ & 40.0 & 6.87 & 1.00 \\
\hline
\end{tabular}




\section{Transport Energy Use and GDP In Mexico}

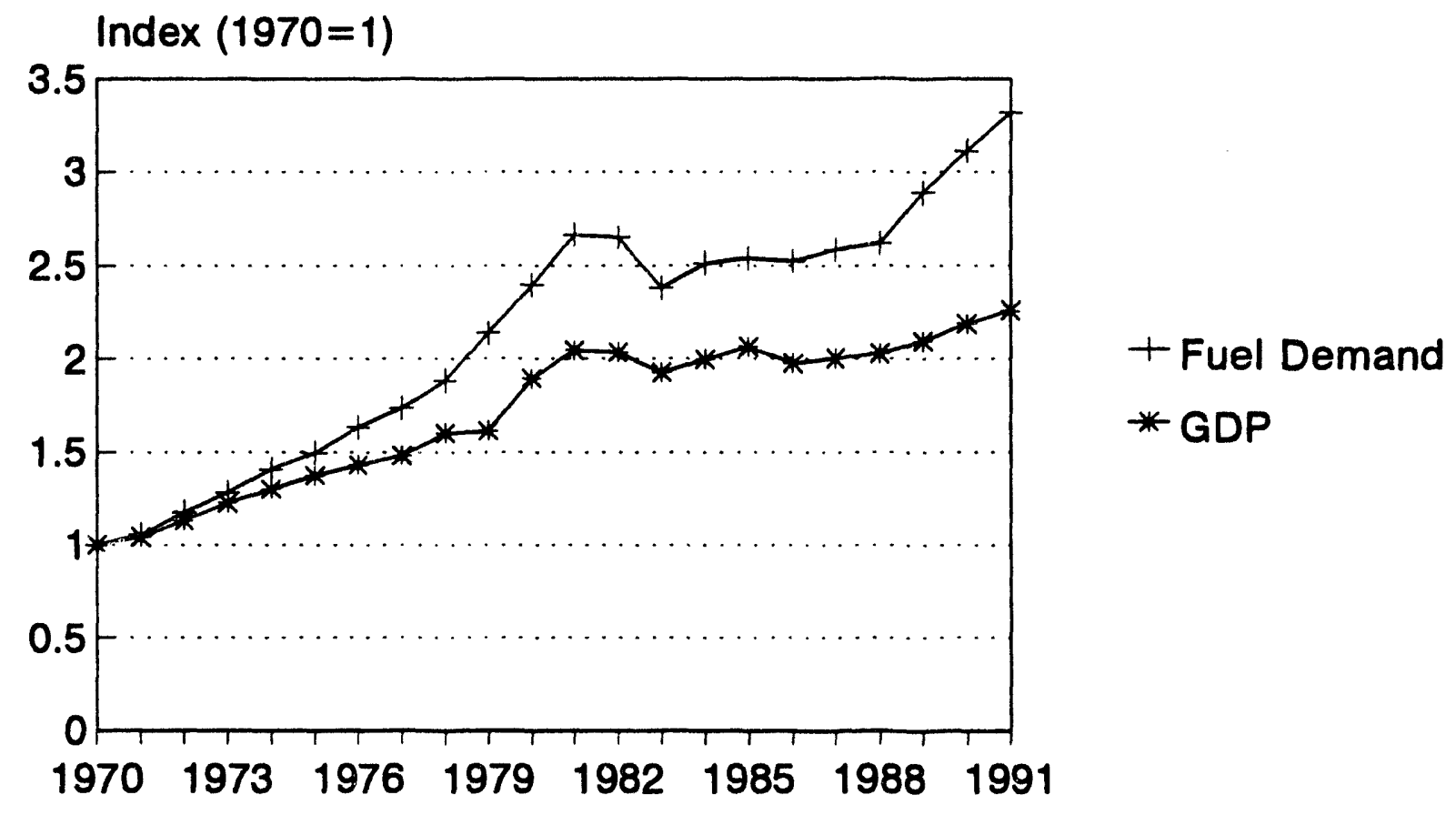

Figure 3.1

\section{Transport Energy Use by Fuel In Mexico}

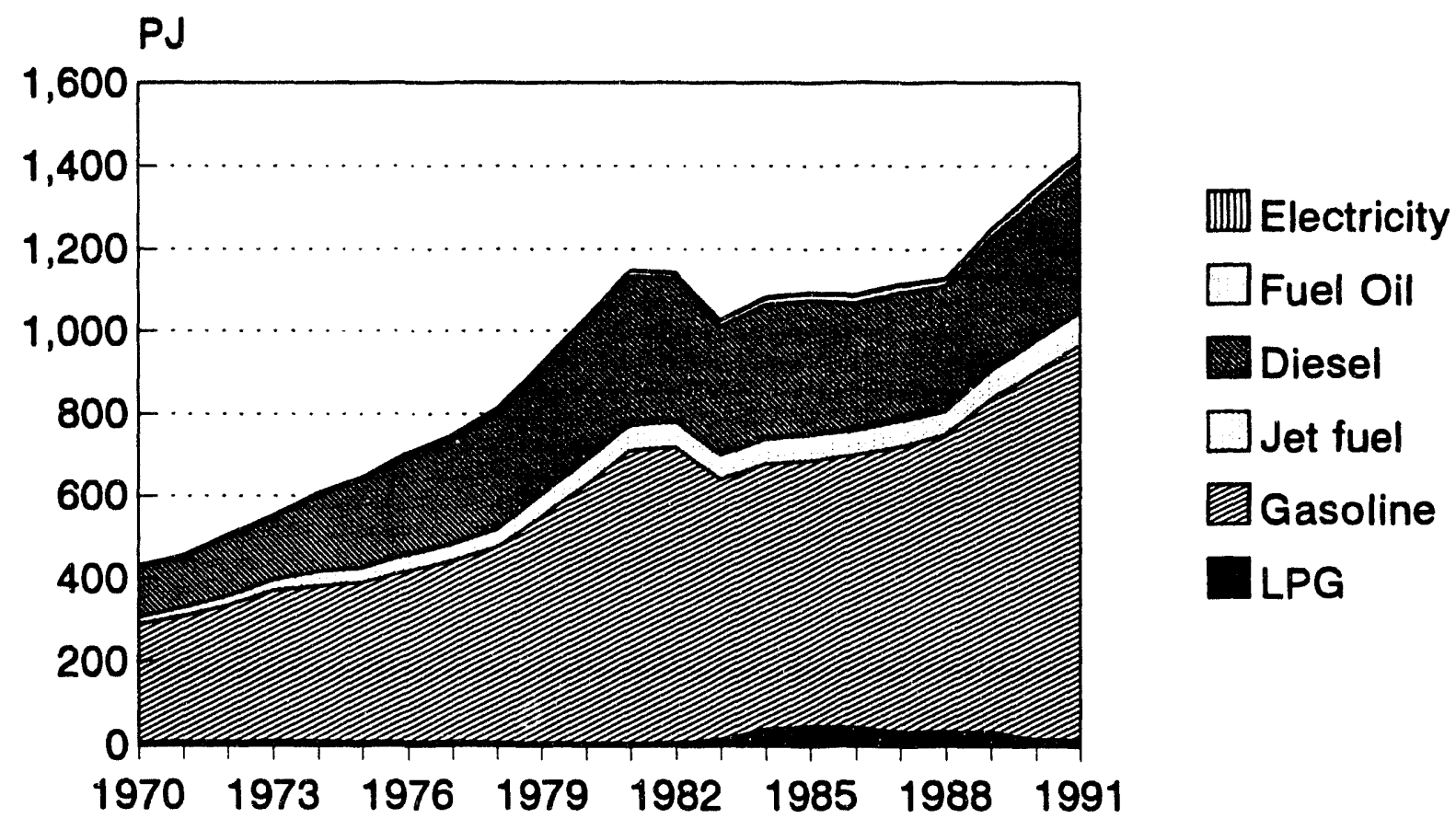

Figure 3.2 


\section{Transport Energy Use by Mode and Fuel in Mexico $1975,1983,1988$}

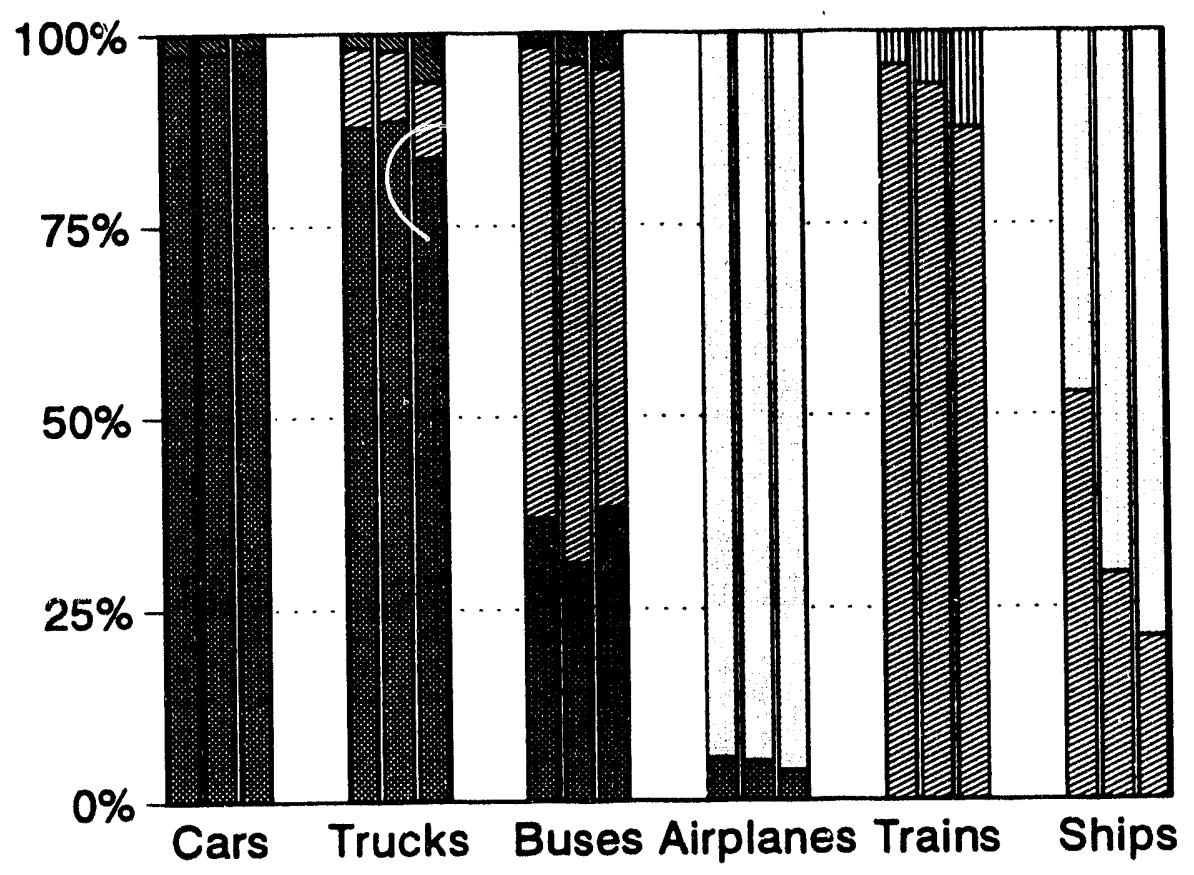

临Electricity

$\square$ Jet fuel

LPG

$\square$ Fuel Oil

Diesel

Gasoline

Figure 3.3

Passenger Bus Saturation

In Mexico

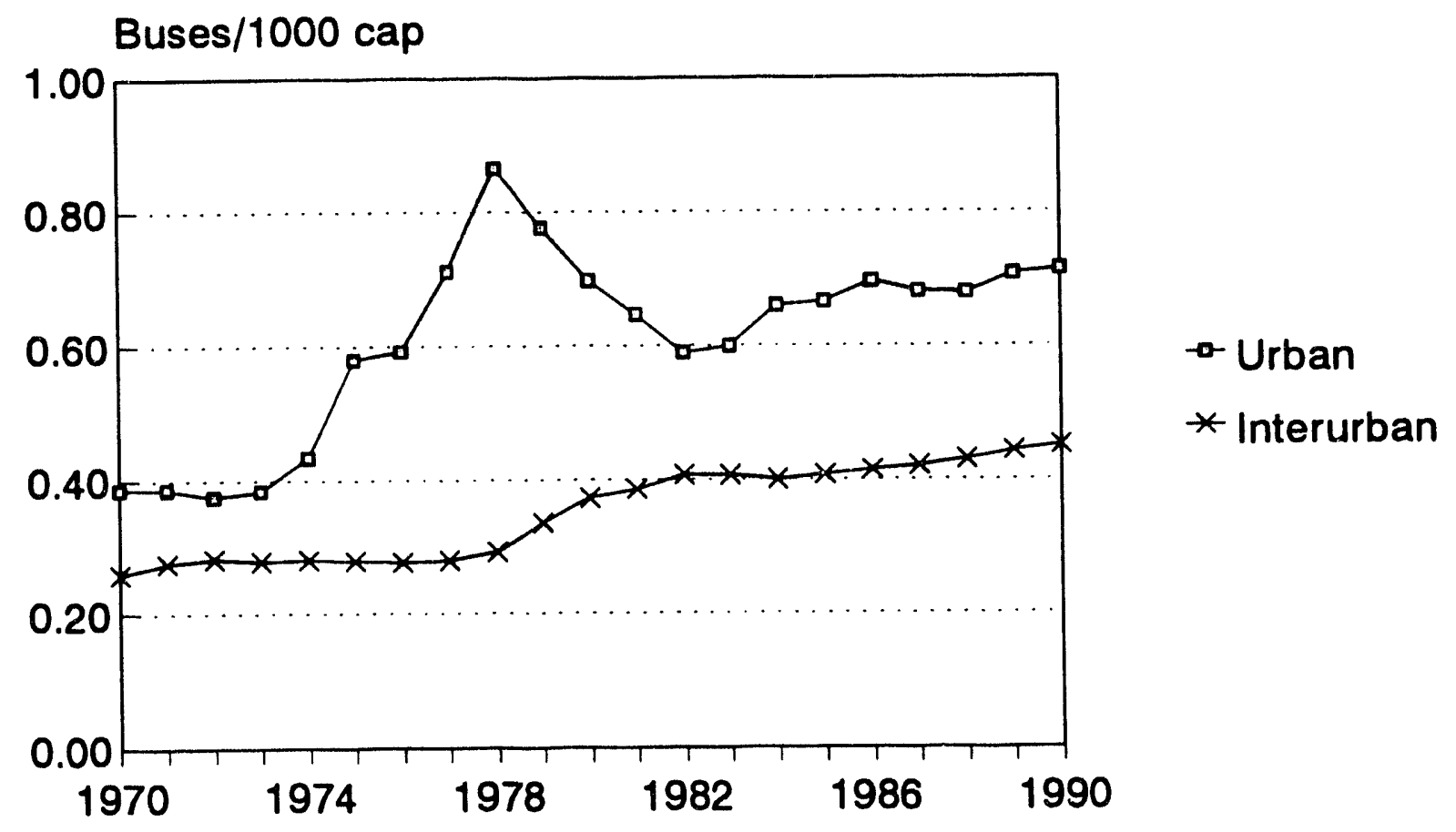

Figure 4.1 


\section{Growth of the Automobile Fleet in Mexico*}

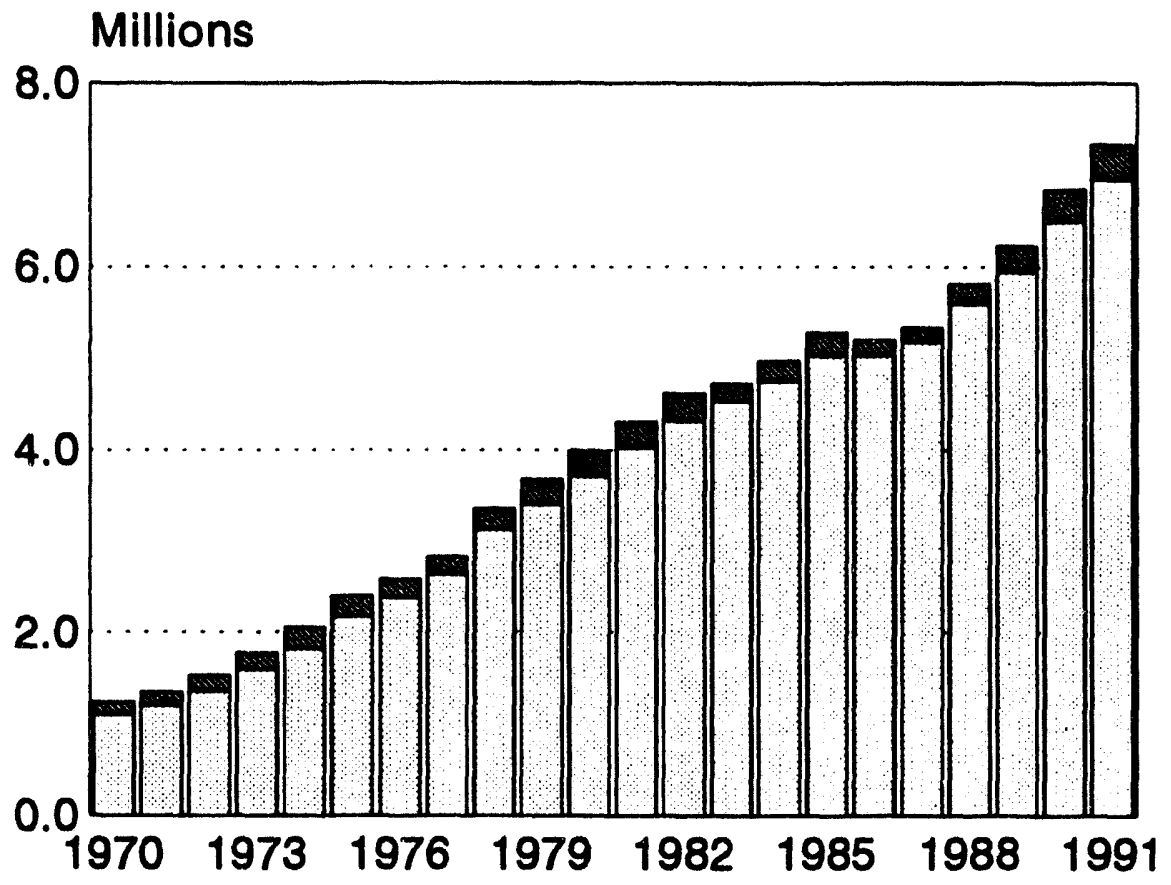

New cars ${ }^{\star \star}$

$\square$ Other cars

* Includes taxis

**Cars purchased in each year

Figure 4.2

\section{Automobile Energy Intensity \\ In Mexico}

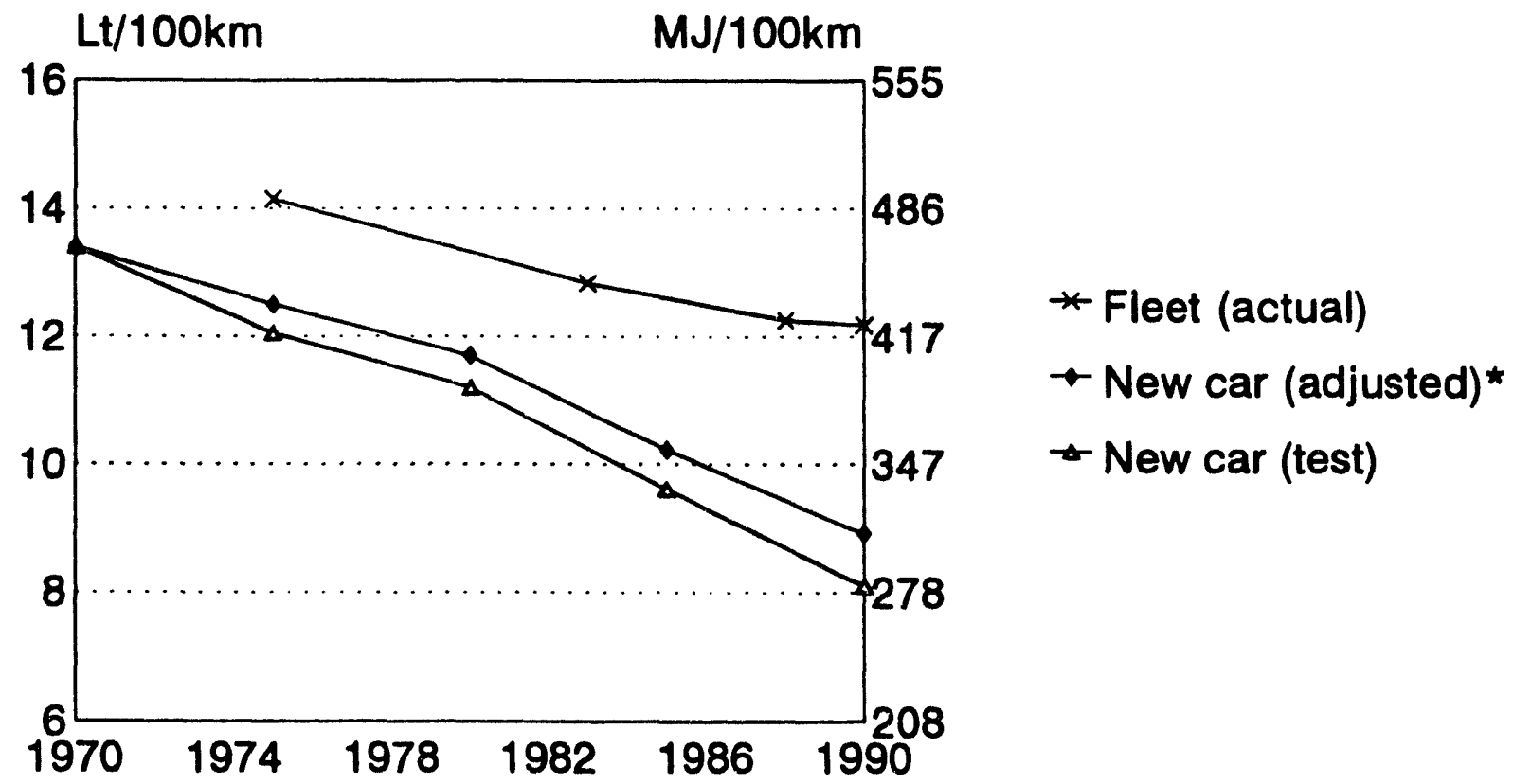

- Holding 1970 new car size mix constant at 1970 configuration.

Figure 4.3 


\section{Structure of New Car Sales In Mexico}

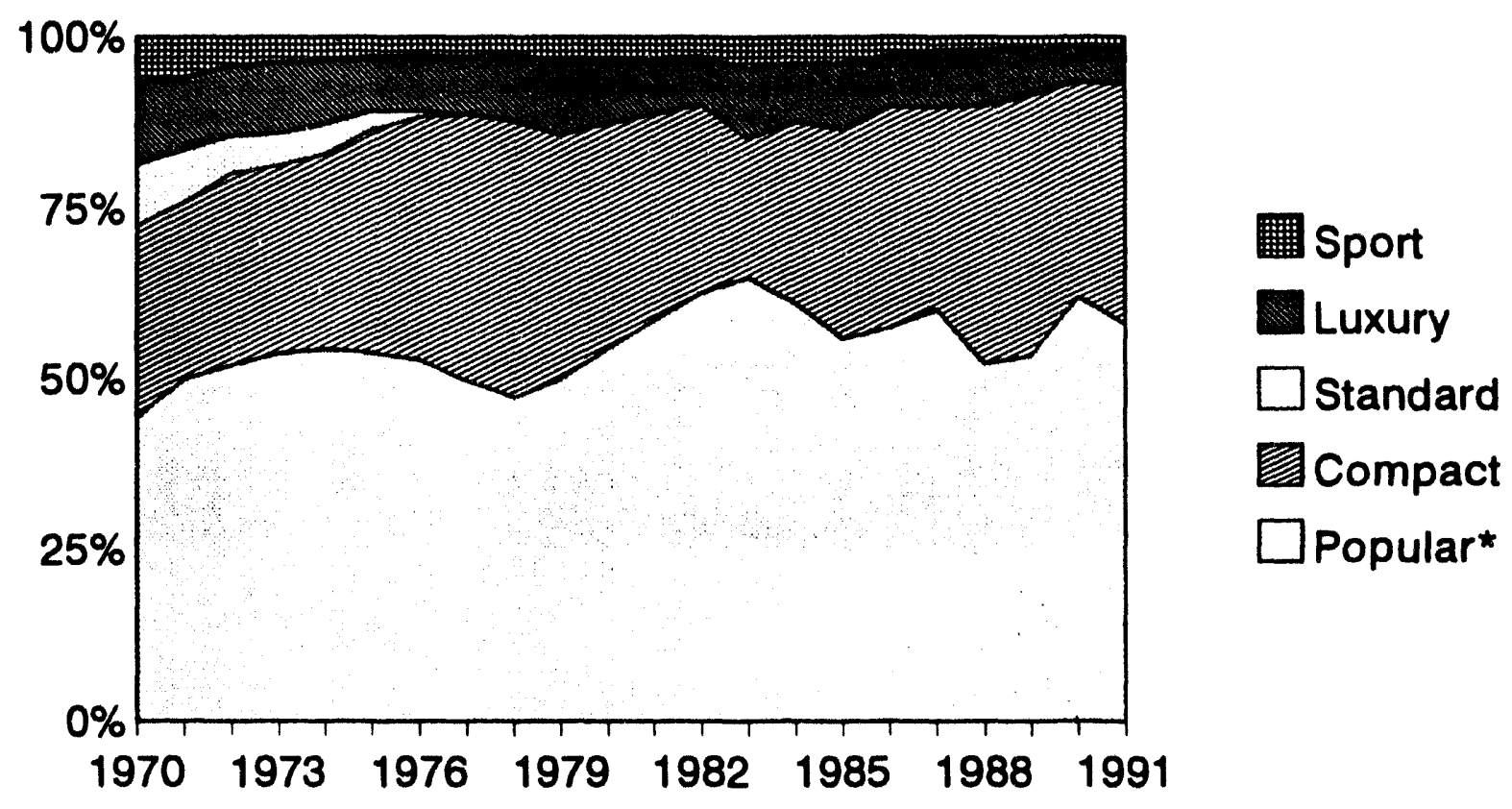

*W bug and Nissan Sentra

Figure 4.4

\section{Share of Total Automobile Purchase Expenditures By Income Level}

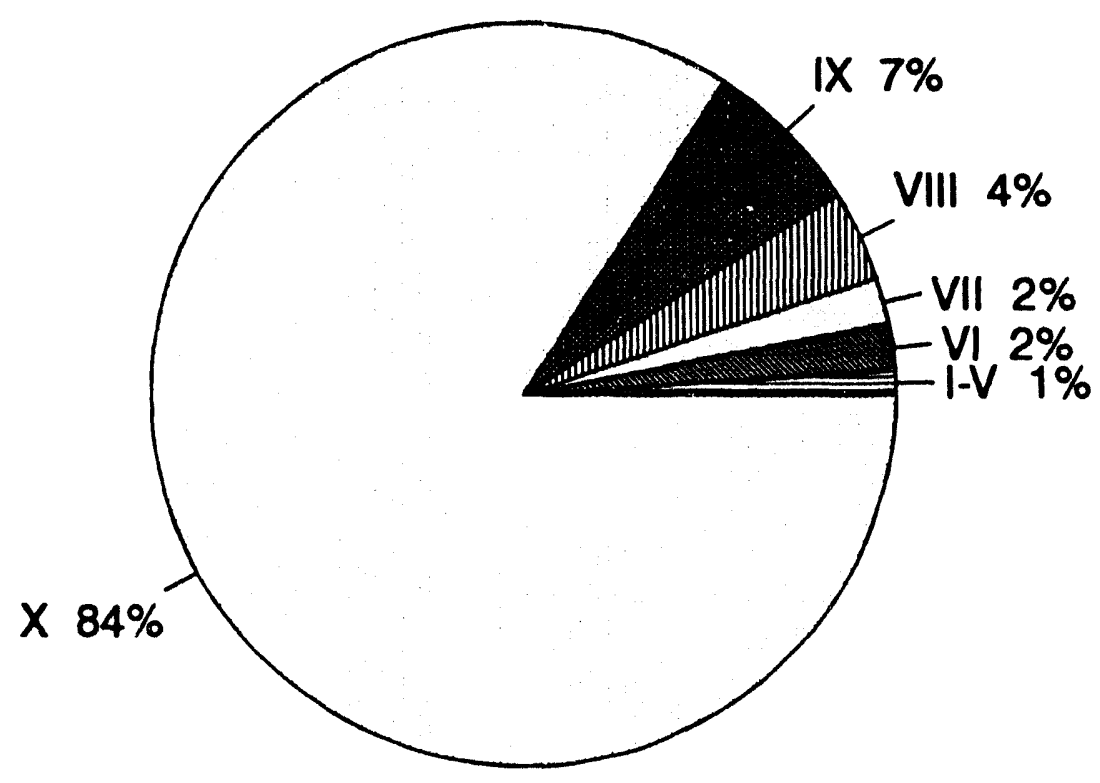

Wealthiest $=X$

Source: Vieyra (1990)

Figure 4.5 


\section{Truck Sales in Mexico}

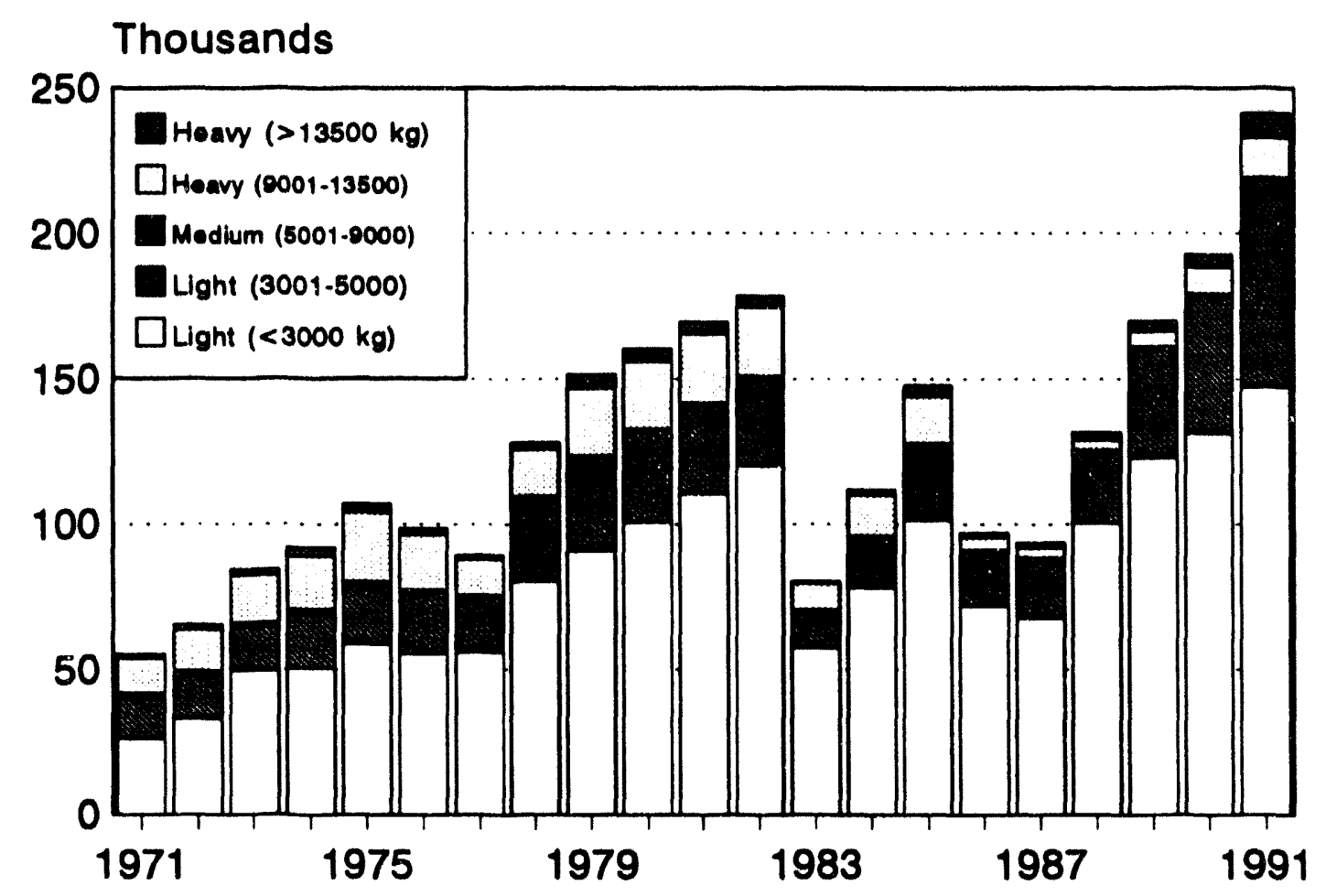

Figure 5.1

\section{Growth of Truck Fleet in Mexico}

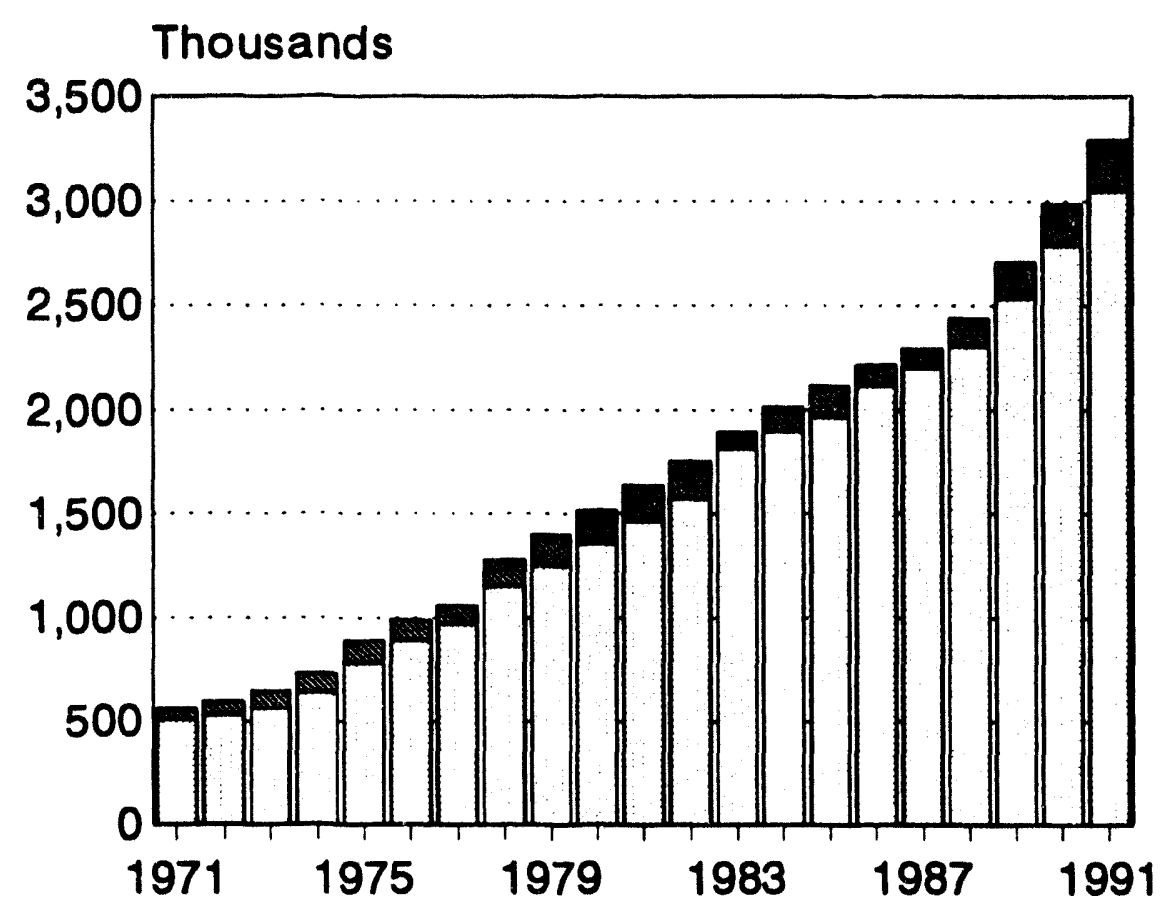

New trucks *

$\square$ other trucks

*Trucks purchased in the year

Figure 5.2 


\section{Transport Energy Prices Real prices (1985 US\$ per liter)}

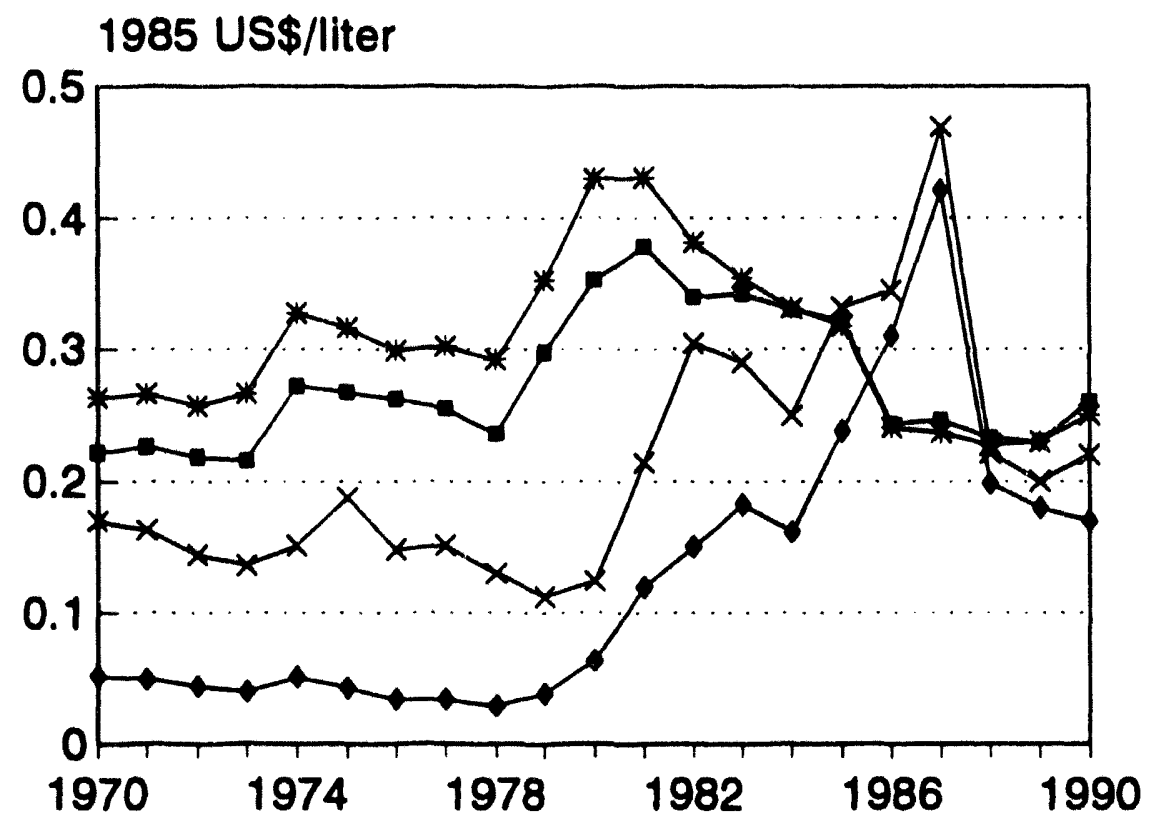

* US Gasoline

$\rightarrow$ US Diesel

* Mex. Gasoline

$\rightarrow$ Mex. Diesel

US prices: LBL; Mexico prices: INEGI

Average prices for premium and regular gasolines.

Figure 6.1

\section{Energy Balance in the MCMA (1992)}

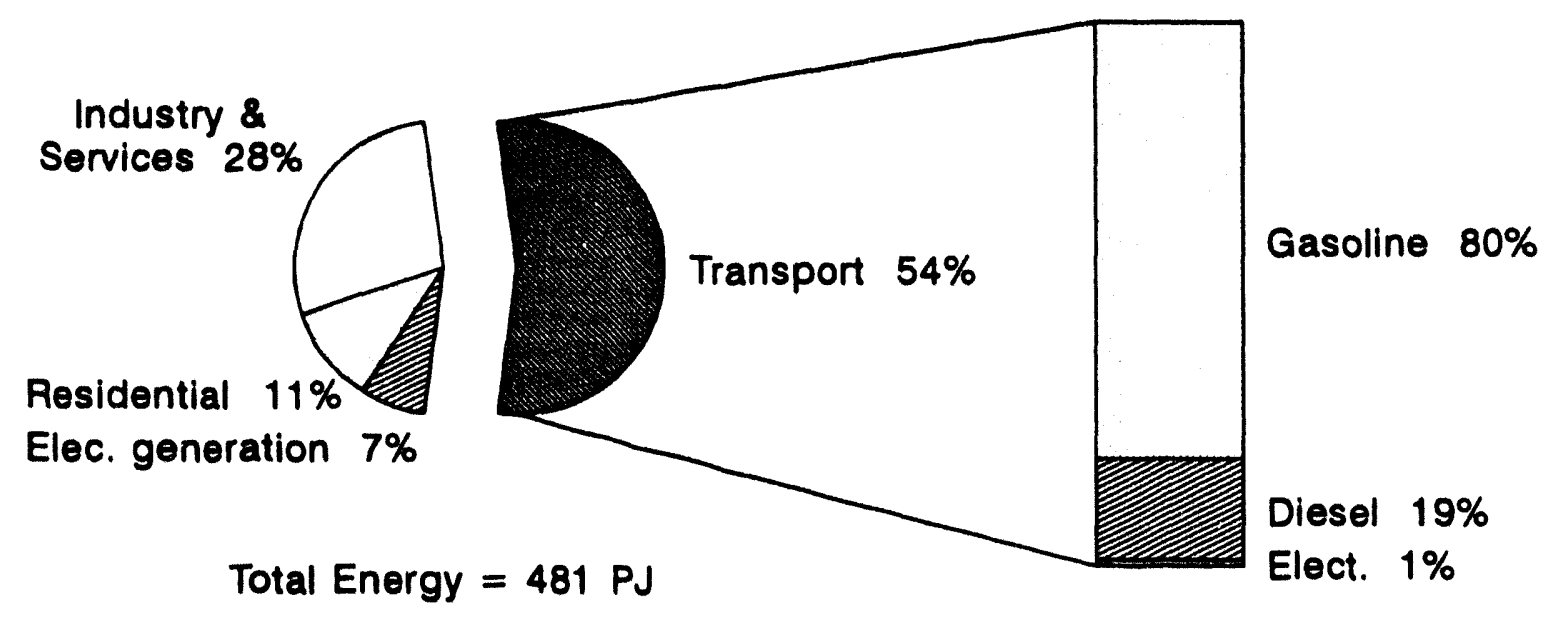

Figure 7.1 


\section{Person Trips per Day in the MCMA Modal shares}

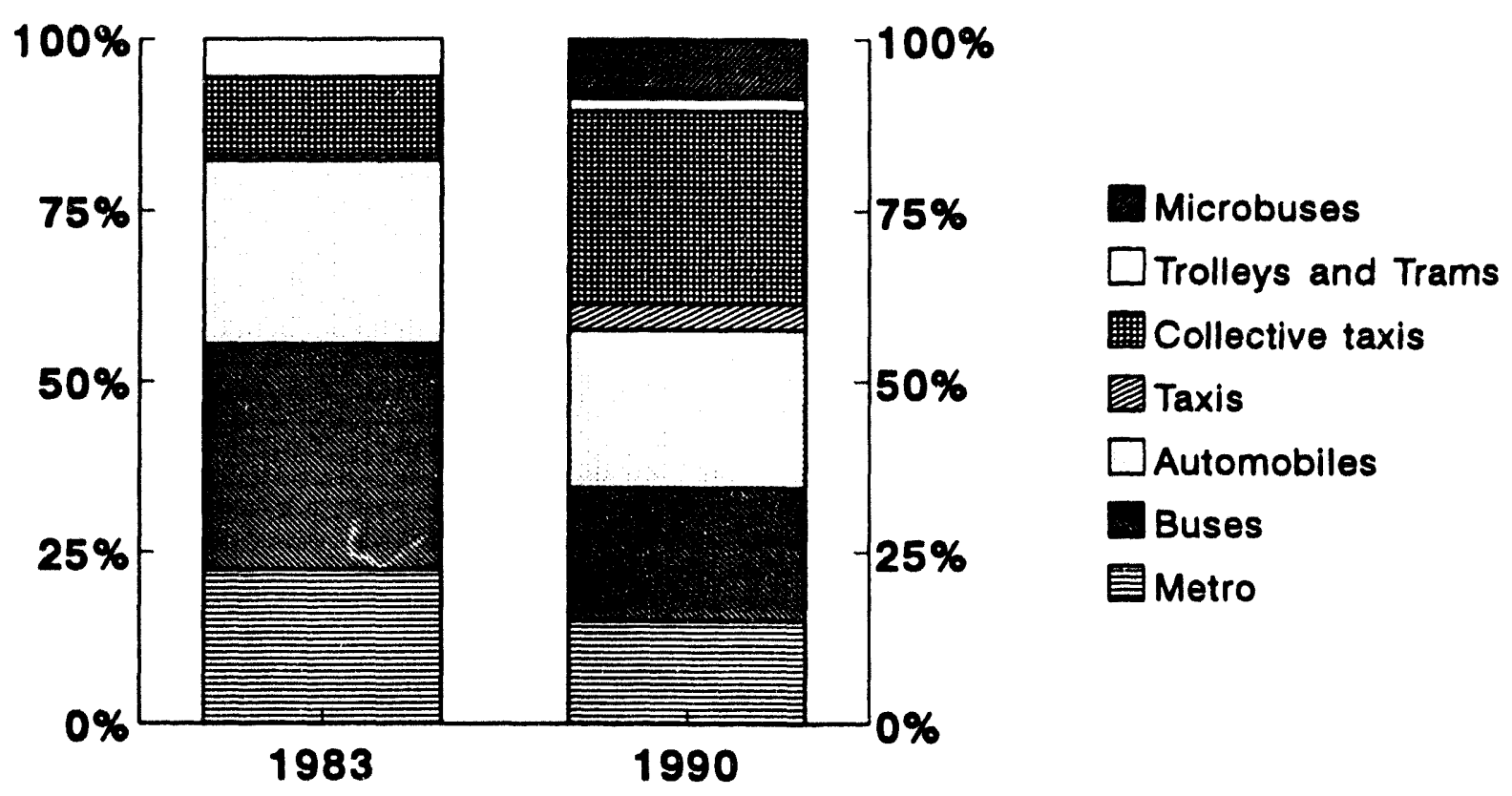

$1983 \cdot 16.02$ million P.T/D $1990 \cdot 39.39$ million P-T/D

Figure 7.2

\section{Passenger-km in the MCMA 1990}

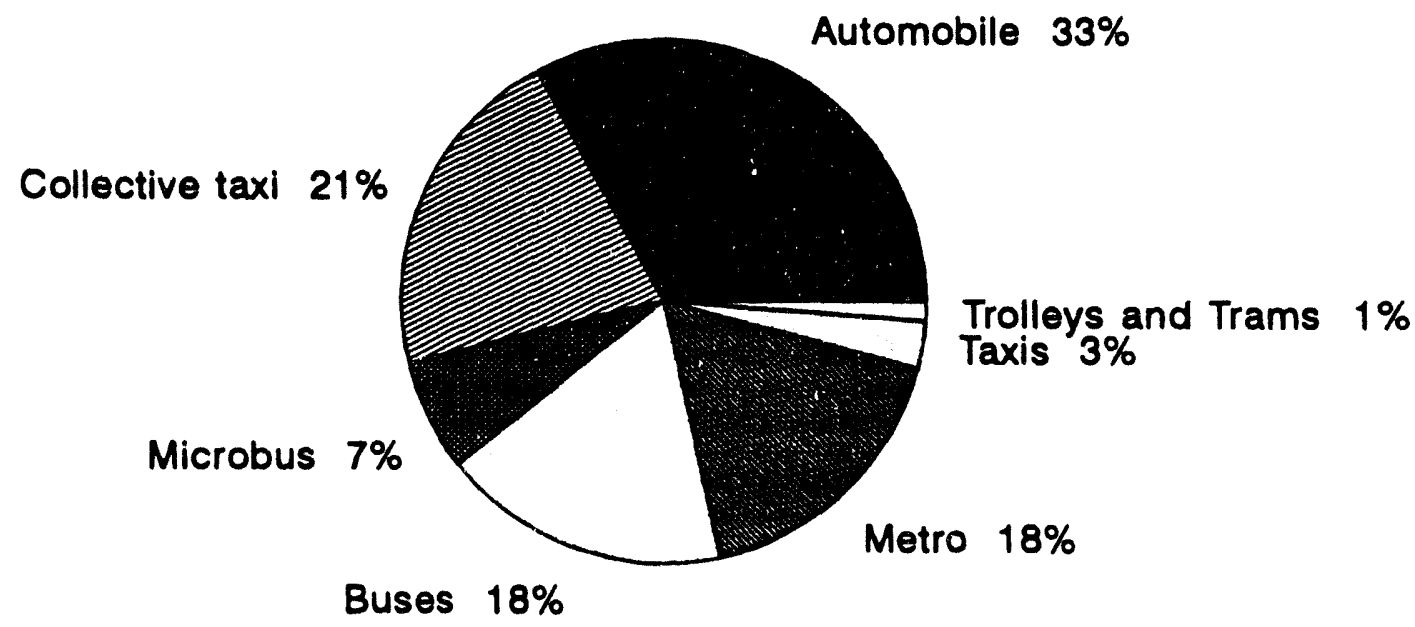

Total P-km $=99.6$ billion

Figure 7.3 


\section{Pollution by Mode in the MCMA (\%) Passenger Transportation}

Hydrocarbons (HC) Carbon Monoxide (CO) Nitrogen oxides (NOx)
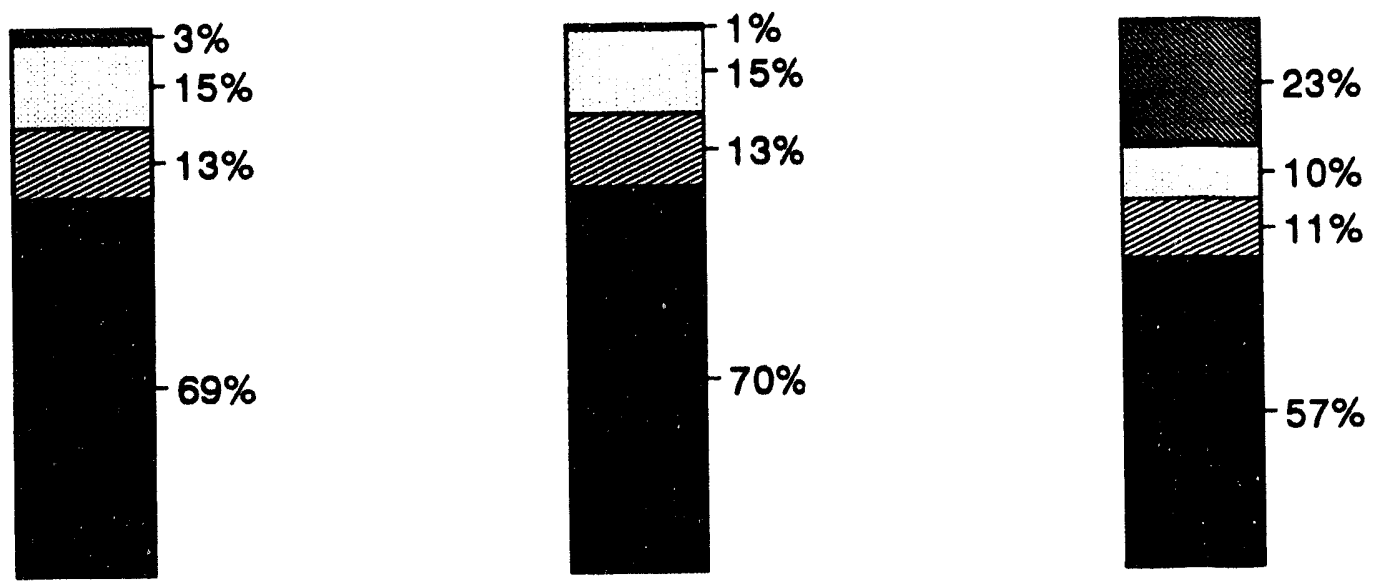

\section{Private cars Taxis $\square$ Collective taxis Others}

Figure 7.4 

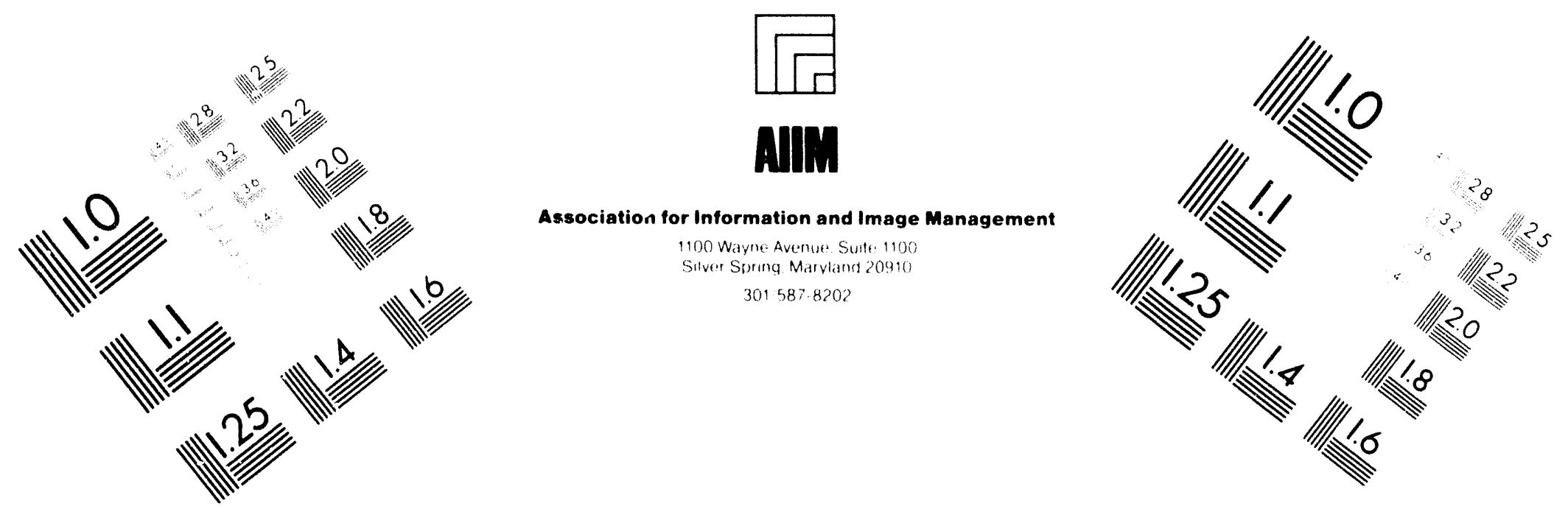

\section{Centimeter}

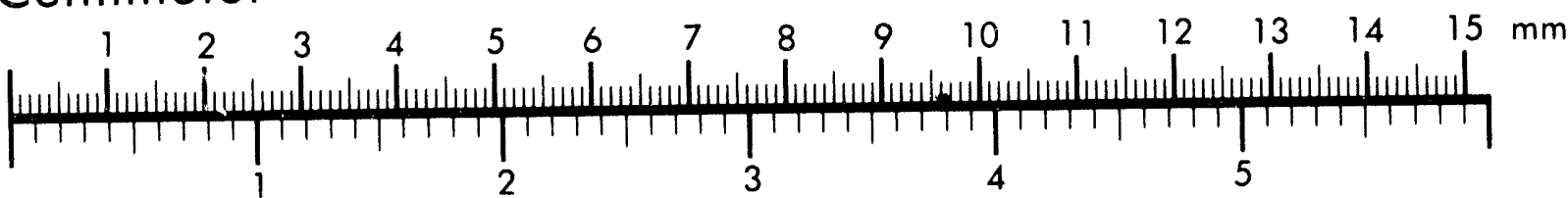
Inches
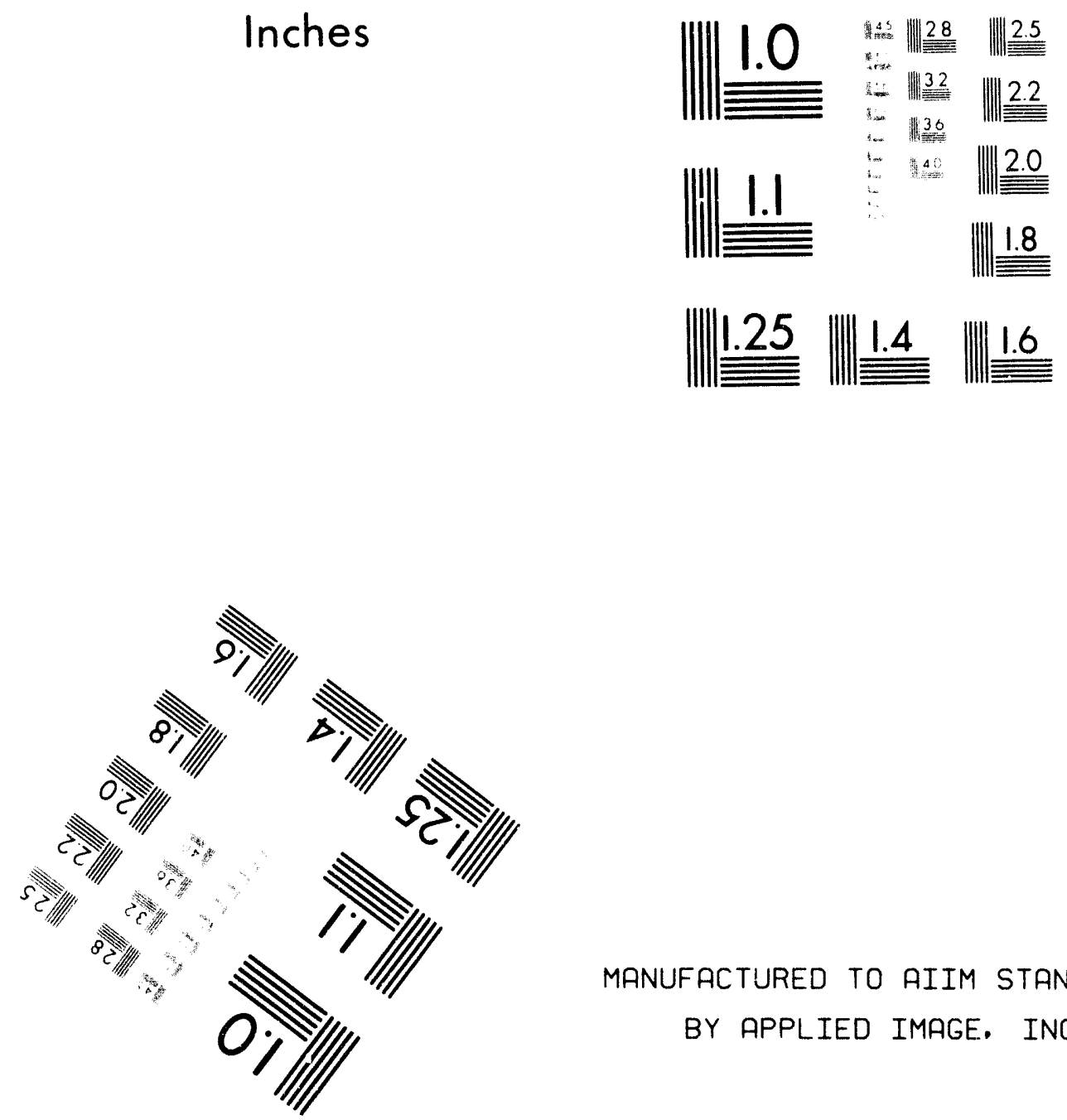

MANUFACTURED TO AIIM STANDARDS

BY APPLIED IMAGE. INC.

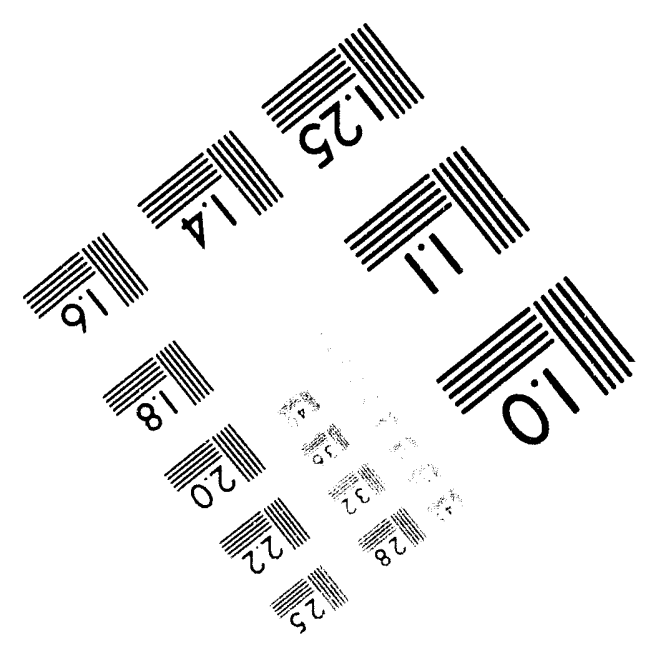




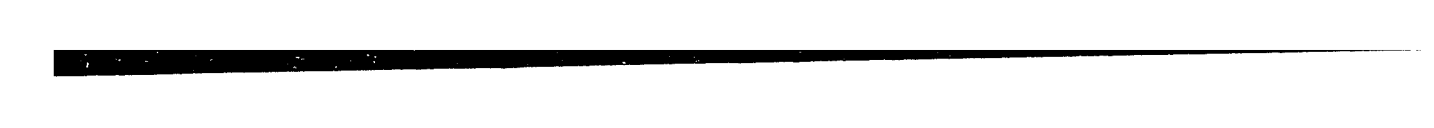

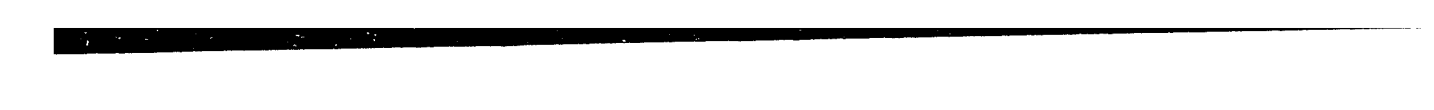
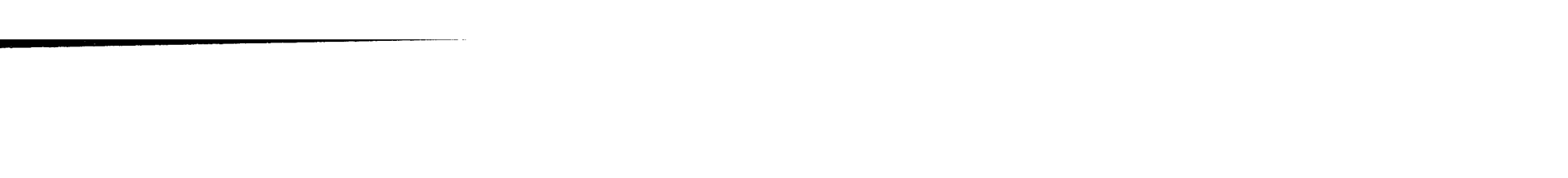

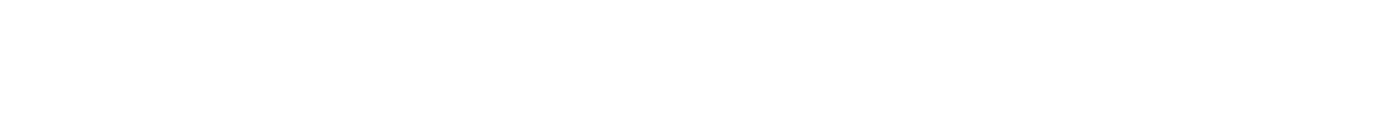

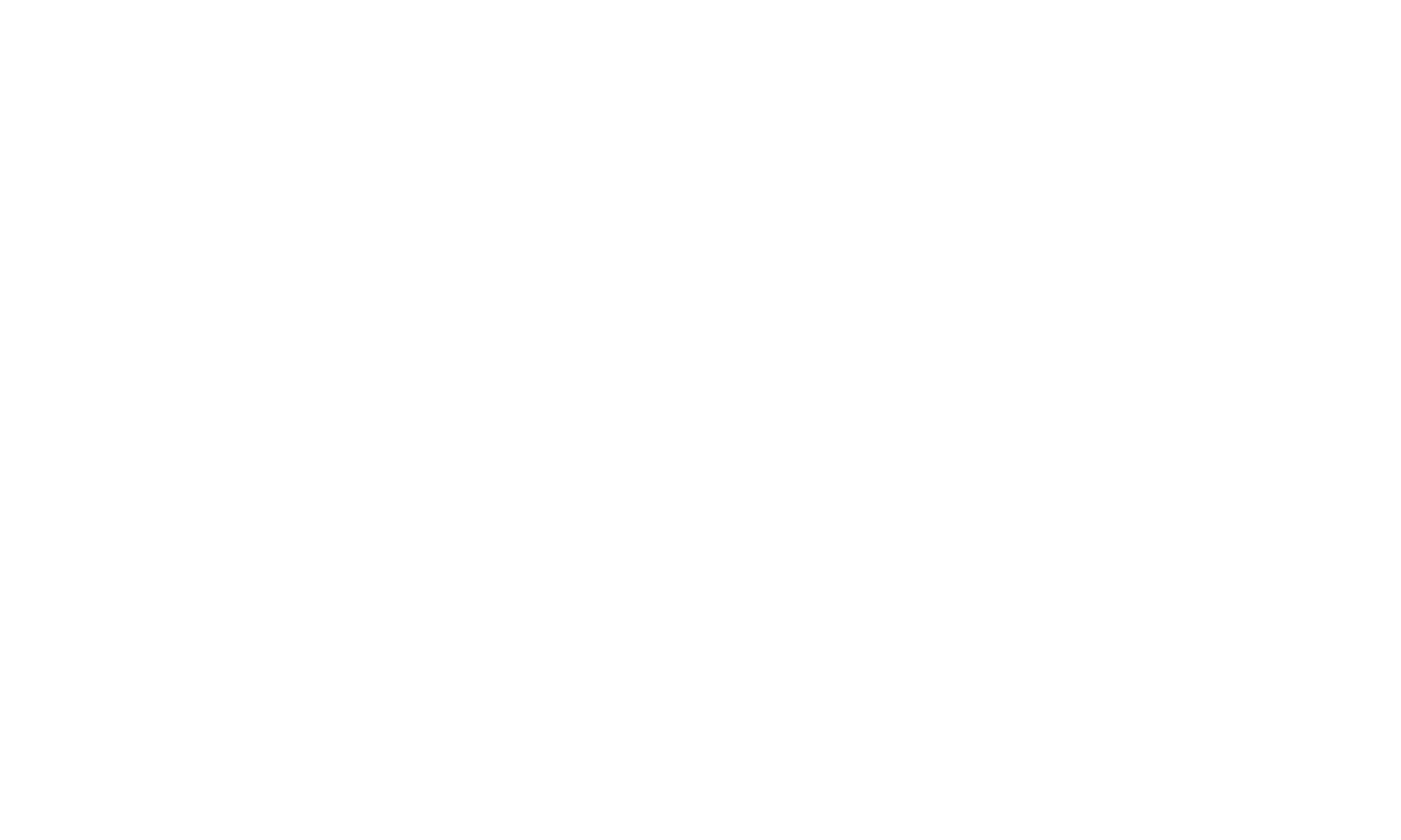
(1)

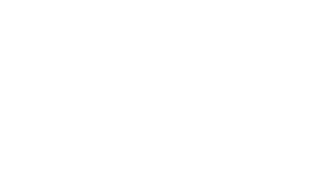

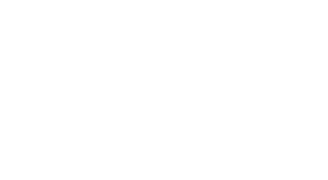

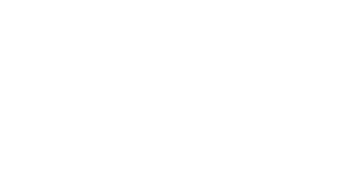

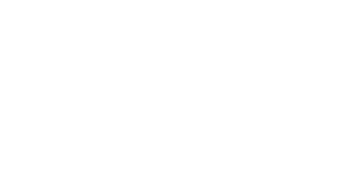

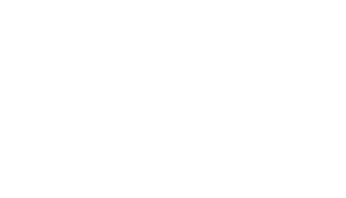
(1) $\left(\frac{10}{10}\right.$

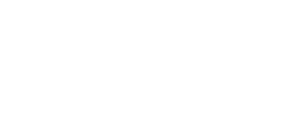
. 

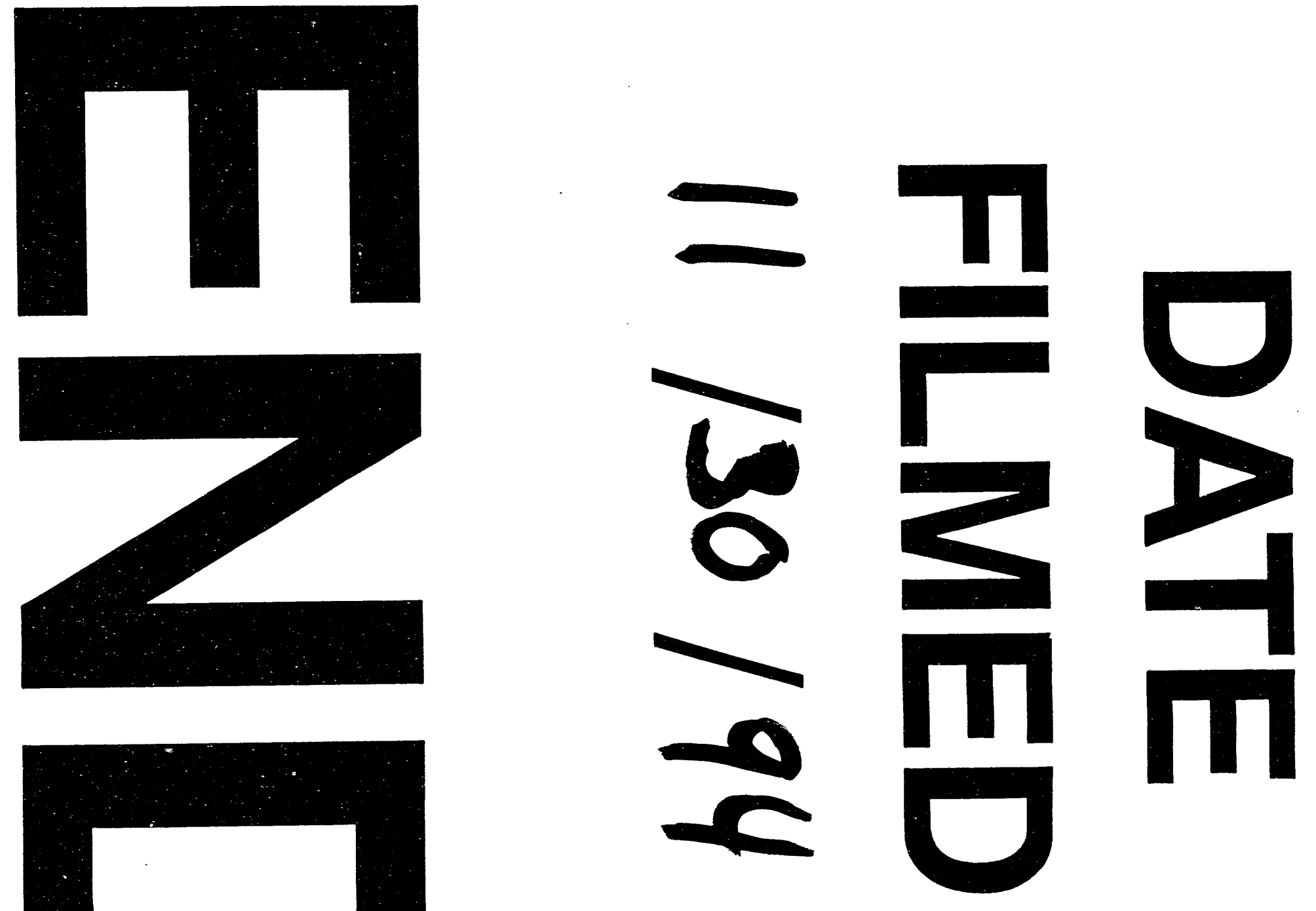